\title{
Phlebotomine sandflies (Diptera, Psychodidae) from the Ankarana tsingy of northern Madagascar: inventory and description of new taxa
}

\author{
Antoine Blavier ${ }^{1}$, Laetitia Laroche ${ }^{1,2}$, Fano José Randrianambinintsoa ${ }^{1}$, Vincent Lucas ${ }^{1}$, Jean-Charles Gantier ${ }^{1}$, \\ Nicole Léger ${ }^{1}$, Vincent Robert ${ }^{2, *}$, and Jérôme Depaquit ${ }^{1,3}$ \\ ${ }^{1}$ Université de Reims Champagne-Ardenne, Faculté de Pharmacie, ANSES, SFR Cap Santé, EA7510 ESCAPE - USC VECPAR, \\ 51 rue Cognacq-Jay, 51096 Reims Cedex, France \\ 2 MIVEGEC Unit, IRD, CNRS, Univ Montpellier, 911 avenue Agropolis, BP 64501, 34394 Montpellier Cedex 5, France \\ ${ }^{3}$ Laboratoire de Parasitologie-Mycologie, CHU de Reims, 51100 Reims, France
}

Received 5 March 2019, Accepted 17 June 2019, Published online 30 June 2019

\begin{abstract}
An inventory of Phlebotomine sandflies was carried out in the Ankarana tsingy located in far northern Madagascar. A total of 723 sandflies were used for morphological, morphometric, and molecular studies (sequencing of partial cytochrome B (mtDNA) and partial 28S (rDNA)). Nine species were identified: Phlebotomus fertei, Sergentomyia anka, Se. sclerosiphon, Se. goodmani, two species of the genus Grassomyia, as well as three new species described herein: Se. volfi n. sp., Se. kaltenbachi n. sp., and Se. ozbeli n. sp. The recognition of these new species is strongly supported by molecular analyses. The first two of the new species could not be classified into any existing subgenus, therefore we proposed two new subgenera (Ranavalonomyia subg. nov., and Riouxomyia subg. nov.), with combinations as: Sergentomyia (Ranavalonomyia) volfi and Sergentomyia (Riouxomyia) kaltenbachi. Our study reveals important molecular variability in $S e$. anka, with the recognition of a population whose taxonomic status remains below that of species. Our research confirms the need to further study the specific diversity of Malagasy sandflies, which until the start of this millennium remained mostly unknown.
\end{abstract}

Key words: Phlebotomine sandflies, Madaphlebotomus, Sergentomyia, Morphological and molecular taxonomy.

Résumé - Les phlébotomes (Diptera, Psychodidae) des tsingy d'Ankarana dans le nord de Madagascar : inventaire et description de nouveaux taxons. Un inventaire des Phlébotomes a été réalisé dans les tsingy d'Ankarana à l'extrême nord de Madagascar. Au total, 723 phlébotomes ont servi à des études morphologique, morphométrique et moléculaire (séquençage d'une partie du cytochrome B (ADNmt) et d'une partie de l'ADNr 28S). Neuf espèces ont été identifiées : Phlebotomus fertei, Sergentomyia anka, Se. sclerosiphon, Se. goodmani, deux espèces du genre Grassomyia, ainsi que trois espèces nouvelles décrites dans ce travail : Se. volfi n. sp., Se. kaltenbachi n. sp., and Se. ozbeli n. sp. L'individualisation de chacune de ces espèces nouvelles est robustement soutenue par les analyses moléculaires. Les deux premières de ces espèces nouvelles ne pouvaient pas être classées dans un sous-genre existant et nous avons proposé pour elles deux sous-genres nouveaux : Ranavalonomyia subg. nov., et Riouxomyia subg. nov, avec les combinaisons Sergentomyia (Ranavalonomyia) volfi et Sergentomyia (Riouxomyia) kaltenbachi. Notre étude révèle une variabilité moléculaire marquée chez $S e$. anka avec l'individualisation d'une population dont le statut taxinomique demeure populationnel. Nos travaux confirment la nécessité de poursuivre l'étude de la biodiversité des Phlébotomes qui est restée méconnue dans ce pays jusqu'au début de ce millénaire.

\section{Introduction}

The diversity of Phlebotomine sandflies (Diptera, Psychodidae) of Madagascar has long been understudied because that this island country is known to be leishmaniasis-free.

*Corresponding author: vincent.robert@ird.fr
Two species belonging to the genus Grassomyia, Gr. squamipleuris Newstead 1912 and Gr. madagascariensis Abonnenc 1969, were initially reported from Madagascar [1, 2]. In 1978, Léger and Rodhain described Phlebotomus berentiensis in the genus Sergentomyia. This sandfly with specific characteristics was moved into the genus Phlebotomus Rondani \& Berté, according to the characteristics of the male 


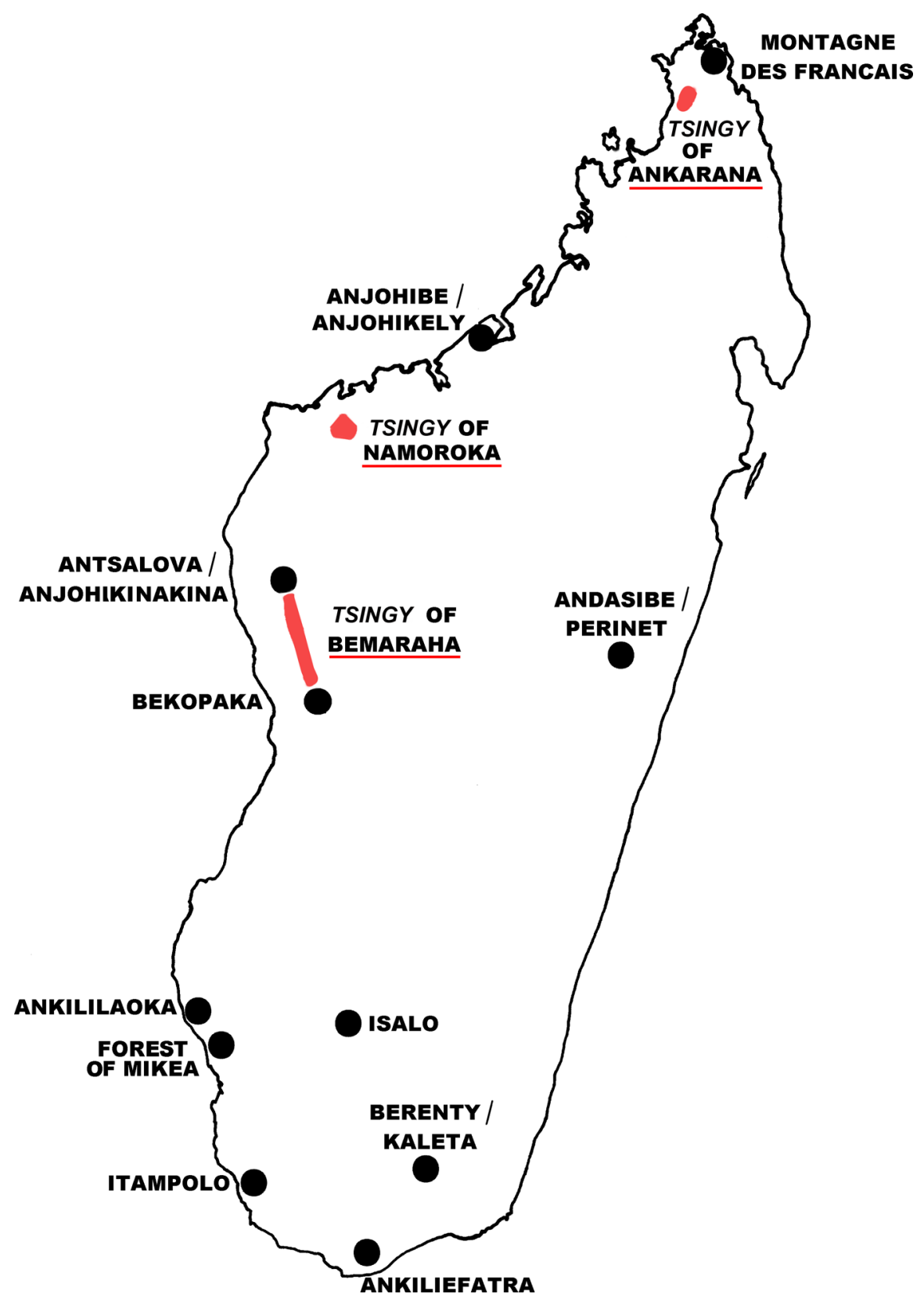

Figure 1. Map of Madagascar showing the tsingy of Ankarana, the other tsingy, and the places where sandflies were caught.

described later [7]. The first record of Phlebotomus in Madagascar was made in 2002 with the description of a male Ph. fertei Depaquit, Léger \& Robert [9]. As of today, 14 species have been identified in Madagascar, including five Phlebotomus: Ph. fertei, Ph. berentiensis, Ph. fontenillei Depaquit, Léger \& Robert 2004, Ph. vaomalalae Randrianambinintsoa, Léger \& Depaquit 2013, and Ph. vincenti Randrianambinintsoa \& Depaquit 2013. All of them belong to the endemic subgenus Madaphlebotomus Depaquit, Léger \& Randrianambinintsoa 2015 [8].

At the present time, the genus Sergentomyia includes seven species: Se. (Trouilletomyia) huberti (Depaquit, Léger \& Robert 2002), Se. (Rondanomyia) goodmani Léger, Depaquit \& Robert 2005, Se. majungaensis Depaquit, Léger \& Robert 2007,
Se. (Vattieromyia) sclerosiphon Depaquit, Léger \& Robert 2008, Se. (Vat.) namo Depaquit, Léger \& Robert 2008, Se. (Vat.) anka Depaquit, Léger \& Robert 2008, and Se. (Tro.) boironis Randrianambinintsoa \& Depaquit 2014 [9, 11, 12, 26, 33].

Our research objective was to investigate the sandflies found in the karst formations (eroded limestone spires), known as tsingy, of the Ankarana region in the far north of the island (Fig. 1).

For a long time, only the species of the genus Phlebotomus, known to take blood-meals on mammals and birds, were considered able to transmit Leishmania in the Old World [23]. However, the genus Sergentomyia, whose role was ignored for too long, cannot be neglected as a potential vector [28]. Many Sergentomyia species feed on reptiles [2, 17], but some 
of them are able to feed on mammals [4, 22, 36]. We do not know whether the Malagasy sandflies could have vectorial competence for some Leishmania. Some Leishmania could be transmitted by sandflies differing from their usual vectors in the New World as well as in the Old World [6, 16, 23, 37]. The role of Malagasy species in Leishmania transmission remains unknown and could be evaluated based on newly colonized species [25].

\section{Materials and methods}

\section{Ethics statement}

A research license for collecting and transporting zoological material (099-MEF/SG/DGEF/DADF/SCB, 5 May 2003) was obtained from Madagascar National Parks and the Ministère des Forêts et de l'Environnement. No endangered or protected species were collected in this study.

\section{Sandfly sampling}

Sampling was carried out at the Réserve Spéciale d'Ankarana, Diana Region (ex-province of Antsiranana) in the northern part of the island, $70 \mathrm{~km}$ south of the town of Antsiranana. The collection site was many kilometers from any human habitation and in an area of dry deciduous forest surrounded by karst formations of eroded limestone spires, known as tsingy. This massif is an outcrop of middle Jurassic limestone, oriented NE-SW and of about $25 \mathrm{~km}$ long and $8 \mathrm{~km}$ wide. Quaternary earth movements (c. 1.5 million years ago) resulted in the splitting of the massif and the elevation of its western wall, which is now marked by vertical cliffs rising $100-150 \mathrm{~m}$ above the surrounding area. A series of volcanic eruptions in recent geological times produced lava flows around the massif, including directly into some of the canyons (0.5 million years ago). The Ankarana Massif is filled with a diversity of water cut canyons, crevices, and many caves. These different formations represent a wide variety of geomorphological types and presumably provide a considerable range of different habitats for invertebrates (Fig. 2). The Ankarana region receives slightly less than $2000 \mathrm{~mm}$ of rainfall annually [20]. Even with this relatively high annual precipitation, the site has dry deciduous vegetation due to a long dry season, lasting most years from May to November, and when the average daily temperature reaches about $26{ }^{\circ} \mathrm{C}$. The rainy season is generally from December to April, and accounts for $93 \%$ of the annual precipitation, and the average daily temperature is $27.5{ }^{\circ} \mathrm{C}$ [18, 27].

Sandflies were collected over seven consecutive nights, between 20 May and 26 May 2003. They were captured using CDC miniature light traps (John W. Hock Company, Gainesville, FL, USA) installed from 5 p.m. to 8 a.m. A total of 40 trap-nights were set, with 19 in caves and 21 in openair settings.

Traps were placed in four separate types of settings: (1) outside of caves (exterior), often in natural forested areas, (2) within the entrance zone of caves, with varying shade and associated fluctuating temperatures, 5-20 m away from the physical opening, depending on the rocky structure, (3) within the dark zone (interior) of caves, completely removed from sunlight and with generally constant temperatures, at a distance less than $100 \mathrm{~m}$ from the cave entrance, and (4) far into the caves at a distance larger than $100 \mathrm{~m}$ from the cave entrance, often at the end of the cave passage.

The localities of all of the Phlebotomine sandflies captured during the May 2003 field trip include (according to WGS84 system):

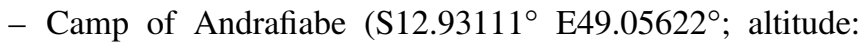
$25 \mathrm{~m}$ above sea level),

- Andrafiabe cave (S12.93006 ${ }^{\circ}$ E49.05936 ${ }^{\circ}$; altitude: $25 \mathrm{~m}$ a.s.1.),

- Antsirohandoa Skeleton cave (S12.93611 ${ }^{\circ}$ E49.05650 altitude: $50 \mathrm{~m}$ a.s.1.), and

- Camp of Anilotra (S12.93611 ${ }^{\circ} \mathrm{E} 49.05650^{\circ}$; altitude: $125 \mathrm{~m}$ a.s.1.).

\section{Morphological analysis}

Sandflies were stored in $96 \%$ ethanol. The head, thorax and genitalia were cut off in a drop of ethanol. Soft tissues were lyzed in a bath of $\mathrm{KOH} 10 \%$, then bleached in Marc-André solution, and mounted between a microscope slide and cover slip in Euparal ${ }^{\circledR}$ for species identification after dehydration in successive alcohol baths. To allow the use of old mounted specimens in chloral gum, some slides were left for several days in a wet room then remounted in Euparal ${ }^{\circledR}$ after complete processing of washing, bleaching, and dehydration. The abdomen related to the specimen was dried and stored in a vial at $-20^{\circ} \mathrm{C}$ before DNA extraction. Visual analysis of the specimens was performed by means of a BX61 microscope (Olympus, Japan). Measurements and counts were made by using Stream Motion software (Olympus, Japan) and a video camera connected to the microscope.

For both sexes, the following head measurements were made: flagellomeres 1-3; labrum-epipharynx; length of palpal segments 1-5; number of cibarial teeth and denticles (vertical teeth). For males belonging to new species, we also measured the lengths of the sperm pump, aedeagal duct, parameral sheath, epandrial lobe, gonocoxite, gonostyle, and the distance between the accessory spine and the top of the gonostyle. The number of ventral setae of the gonocoxite was also determined.

Drawings were made using a camera lucida. Identifications were carried out using the keys and papers [7-12, 26, 30, 32, 33] related to Malagasy Phlebotomine sandflies, as well as other keys [1, 2, 29].

The terminology adopted for the characters is the most recent one for Phlebotomine sandflies [15].

All morphological measurements were tested for normality by a D'Agostino-Pearson omnibus K2 non-parametric normality test (GraphPad Prism version 6.07 for Windows, GraphPad Software, San Diego, CA, USA). Multifactorial analysis (principal component analysis and hierarchical clustering) was also used to investigate the distribution (homogeneity and clustering) of sandfly measurements by means of XLStat 2018 software (Addinsoft, Paris, France). 

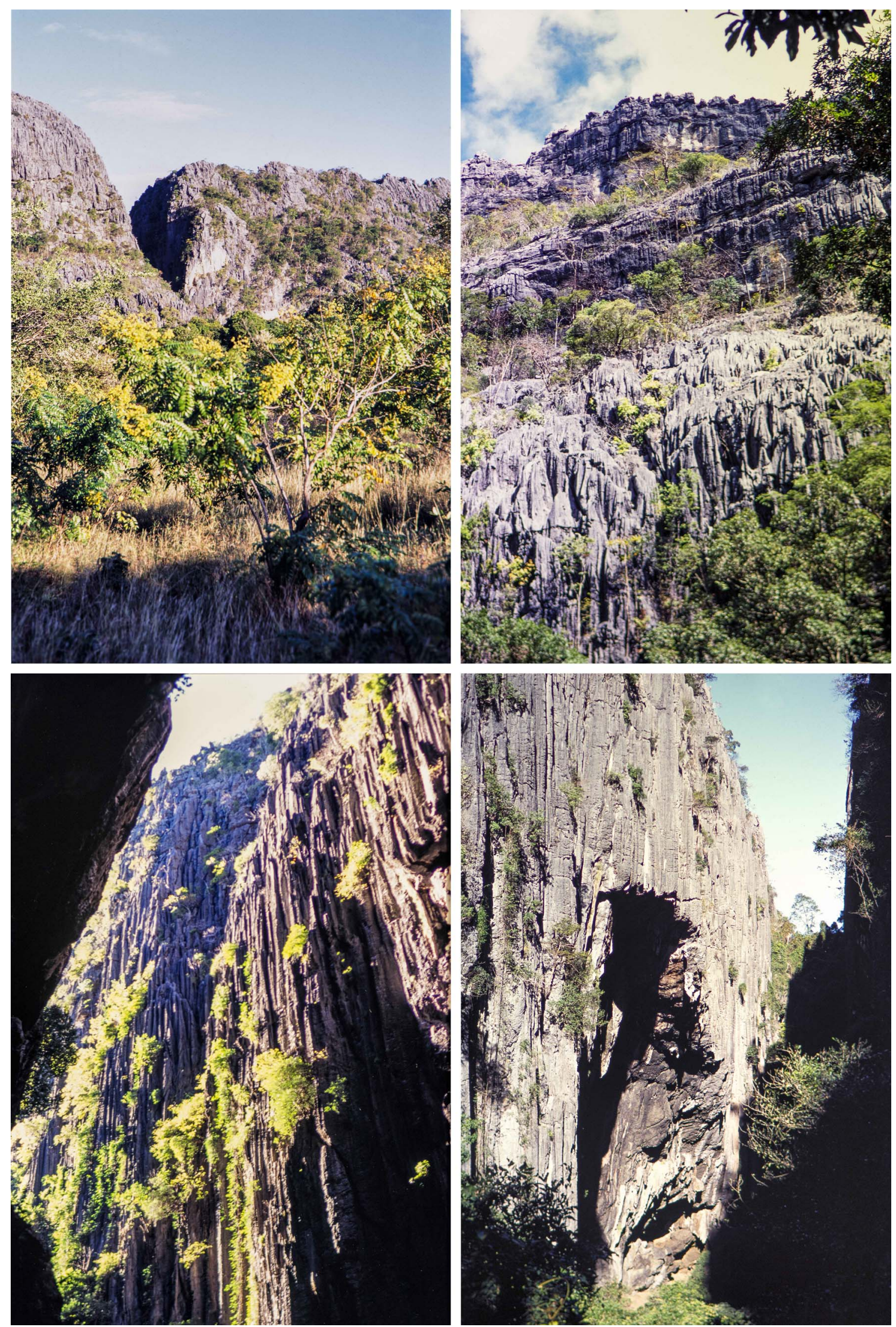

Figure 2. Four photos of the Tsingy of Ankarana taken in May 2003. Photos: Vincent Robert. 


\section{Molecular analysis}

Genomic DNA was extracted from the first segments of the abdomen of individual sandflies using the QIAmp DNA Mini Kit (Qiagen, Germany) following the manufacturer's instructions, except for crushing sandfly tissues with a piston pellet (Treff, Switzerland), and using an elution volume of 50-200 $\mu \mathrm{L}$ [7].

A fragment of cytochrome b (Cyt b) (using the C3B-PDR: 5'-CAYATTCAACCWGAATGATA- ${ }^{\prime}$ and N1N-PDR: $5^{\prime}$ GGTAYWTTGCCTCGAWTTCGWTATGA- $3^{\prime}$ primers) and the D1 and D2 fragments of $28 \mathrm{~S}$ rDNA (using the $\mathrm{C1}^{\prime}: 5^{\prime}$-ACCCGCTGAATTTAAGCAT- $3^{\prime}$ and D2: $5^{\prime}$-TCCGTGTTTCAAGACGGG-3' primers) were amplified by PCR $[13,14]$.

Amplicons were analyzed by electrophoresis in $1.5 \%$ agarose gel containing Gel Green at a concentration of $0.005 \% \mathrm{~V} / \mathrm{V}$. Direct sequencing in both directions was performed using the primers used for DNA amplification. Sequence correction was performed by using Pregap and Gap softwares included in the Staden Package [5].

Consensus sequences were aligned by the Clustal W algorithm [38] from the BioEdit 4.8.10 sequence editor [19], and corrected manually.

The sequences obtained during the present study have been compared with all the sequences available in GenBank related to the cyt $b$ and D1-D2 sequences of sandflies from Madagascar and the Comoros Archipelago.
Sequence data were analyzed by MEGA7 [24] based on maximum likelihood. The maximum likelihood trees were constructed by using the substitution model HKY85. All positions containing gaps and missing data were removed from the analyses.

\section{Results}

A total 723 Phlebotomine sandflies were used for morphological and/or molecular analyses (Table 1).

The sandflies belonged to three genera: Phlebotomus, Sergentomyia, and Grassomyia, in accordance with the systematic revision of Abonnenc \& Léger [3] and considering Grassomyia as a genus and not as a subgenus of Sergentomyia. Our sampling included at least nine species (Table 2).

In the Ankarana collection, only one species in the genus Phlebotomus, Ph. fertei, was identified and was represented by 120 specimens. The subgenus Vattieromyia of the genus Sergentomyia was the most abundant, with Se. sclerosiphon representing about $50 \%$ of the sandflies caught and Se. anka about $25 \%$.

With regards to the genus Grassomyia, only four specimens (three males and one female) were captured. Taking into account: (i) our limited sampling, (ii) the process involved for molecular analysis of the thorax, and (iii) the unresolved systematics of this group, we limited our identifications to the

Table 1. Distribution of sandflies collected in the Ankarana tsingy.

\begin{tabular}{|c|c|c|c|c|c|c|c|c|}
\hline Genus & Subgenus & Species & Females & Males & Total & Species $(\%)$ & Subgenus (\%) & Genus $(\%)$ \\
\hline Phlebotomus & Madaphlebotomus & fertei & 38 & 82 & 120 & 16.60 & 16.60 & 16.60 \\
\hline \multirow[t]{7}{*}{ Sergentomyia } & Vattieromyia & sclerosiphon & 218 & 150 & 368 & 50.90 & 75.93 & 82.85 \\
\hline & & anka & 97 & 84 & 181 & 25.03 & & \\
\hline & Rondanomyia & goodmani & 1 & & 1 & 0.14 & 0.69 & \\
\hline & & ozbeli n. sp. & 4 & & 4 & 0.55 & & \\
\hline & Ranavalonomyia subg. nov. & volfi n. sp. & 16 & 13 & 29 & 4.01 & 4.01 & \\
\hline & Riouxomyia subg. nov. & kaltenbachi $\mathrm{n} . \mathrm{sp}$. & 1 & & 1 & 0.14 & 0.14 & \\
\hline & Undetermined & & & & 15 & 2.07 & 2.07 & \\
\hline Grassomyia & & spp & 1 & 3 & 4 & 0.55 & 0.55 & 0.55 \\
\hline Total & & & 376 & 332 & 723 & 100 & 100 & 100 \\
\hline
\end{tabular}

Table 2. Summary of sandflies collection in the Ankarana tsingy in relation with trap position.

\begin{tabular}{|c|c|c|c|c|c|}
\hline & \multicolumn{4}{|c|}{ Location of traps } & \multirow[t]{2}{*}{ Total } \\
\hline & Outside & Entrance of the cave & Middle cave & Cave bottom & \\
\hline Number of traps set up & 21 & 4 & 10 & 5 & 40 \\
\hline Number of positive traps & 17 & 4 & 6 & 1 & 28 \\
\hline Number of sandflies caught & 248 & 127 & 344 & 5 & 724 \\
\hline Mean number of sandflies per trap & 11.8 & 31.8 & 34.4 & 1.0 & 18.1 \\
\hline Ph. fertei & 19 & 71 & 30 & 0 & 120 \\
\hline Se. anka & 99 & 12 & 70 & 0 & 181 \\
\hline Se. sclerosiphon & 102 & 42 & 221 & 3 & 368 \\
\hline Se. goodmani & 1 & 0 & 0 & 0 & 1 \\
\hline Se. ozbeli n. sp. & 1 & 1 & 2 & 0 & 4 \\
\hline Se. volfi $\mathrm{n} . \mathrm{sp}$. & 15 & 0 & 12 & 2 & 29 \\
\hline Se. kaltenbachi n. sp. & 0 & 0 & 1 & 0 & 1 \\
\hline Grassomyia spp. & 4 & 0 & 0 & 0 & 4 \\
\hline Undetermined & 8 & 1 & 6 & 0 & 15 \\
\hline
\end{tabular}




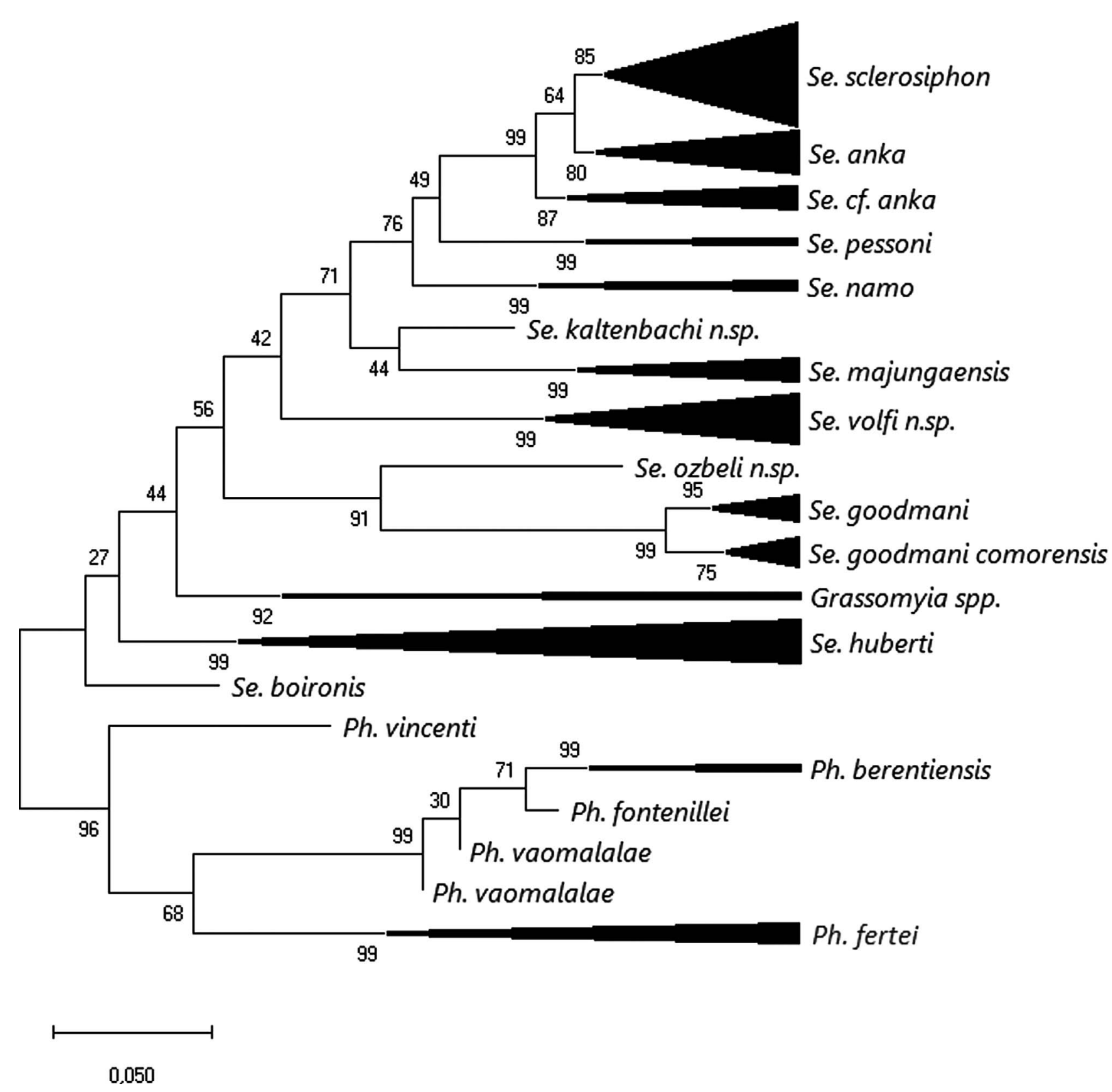

Figure 3. Maximum likelihood tree obtained from partial cyt B sequences based on the HKY 85 model after rooting on Phlebotomus spp. The tree with the highest log likelihood $(-2203.9)$ is shown. The percentage of trees in which the associated taxa clustered together is shown next to the branches. The tree is drawn to scale, with branch lengths measured in the number of substitutions per site. The analysis involved 126 nucleotide sequences.

genus level. The female exhibited 40 cibarial teeth, which is in agreement with Gr. madagascariensis according to Abonnenc (1969). The males, however, exhibited 12, 19, and 25 cibarial teeth, which is more than the 10-15 teeth reported by Abonnenc (1969) for this species [1]. Hence, our samples probably included more than one species.

Regarding the genus Sergentomyia, one specimen of Se. goodmani was captured. This species was previously only known from the Namoroka tsingy and Ankiliefatra.

Three undescribed species of Sergentomyia were collected at Ankarana. According to the morphology of their spermathecae, two of these taxa could not be classified into any existing subgenus. We thus propose two new subgenera.

The number of individuals collected was notably variable, depending on the location of the traps (Table 2). Four trap positions were used with respect to the cave sites: outside, in the entrance, in the middle section, and deep inside. Interesting differences were noted concerning the number of sandflies caught per trap. The mean number of sandflies per trap was the highest in the middle section and in the cave entrance. A significantly lower number was observed outside, and the lowest mean number of captures was observed deep inside the caves (one 
Table 3. Genetic distances between taxa based on cyt B mtDNA sequences. In bold, the intraspecific distances.

\begin{tabular}{|c|c|c|c|c|c|c|c|c|c|c|c|c|c|c|c|c|c|c|c|}
\hline & $\begin{array}{c}\text { Se. } \\
\text { sclerosiphon }\end{array}$ & $\begin{array}{c}\text { Se. } \\
\text { anka }\end{array}$ & $\begin{array}{c}\text { Se. } \\
c f \\
\text { anka }\end{array}$ & $\begin{array}{c}\text { Se. } \\
\text { pessoni }\end{array}$ & $\begin{array}{c}\text { Se. } \\
\text { namo }\end{array}$ & $\begin{array}{c}\text { Se. } \\
\text { kaltenbachi } \\
\text { n. sp. }\end{array}$ & $\begin{array}{c}\text { Se. } \\
\text { majungaensis }\end{array}$ & $\begin{array}{c}\text { Se. } \\
\text { ozbeli } \\
\text { n. sp. }\end{array}$ & $\begin{array}{c}\text { Se. } \\
\text { goodmani }\end{array}$ & $\begin{array}{c}\text { Se. } \\
\text { goodmani } \\
\text { comorensis }\end{array}$ & $\begin{array}{c}\text { Se. } \\
\text { volfi } \\
\text { n. sp. }\end{array}$ & $\begin{array}{c}\text { Se. } \\
\text { boironis }\end{array}$ & $\begin{array}{c}\text { Se. } \\
\text { huberti }\end{array}$ & $\begin{array}{c}\text { Grassomyia } \\
\text { spp. }\end{array}$ & $\begin{array}{c}\text { Ph. } \\
\text { vincenti }\end{array}$ & $\begin{array}{c}P h . \\
\text { berentiensis }\end{array}$ & $\begin{array}{c}P h . \\
\text { fontenillei }\end{array}$ & $\begin{array}{c}P h . \\
\text { vaomalalae }\end{array}$ & $\begin{array}{c}P h . \\
\text { fertel }\end{array}$ \\
\hline Se. sclerosiphon & 0.003 & & & & & & & & & & & & & & & & & & \\
\hline Se anka & 0.028 & 0.005 & & & & & & & & & & & & & & & & & \\
\hline Se. cf anka & 0.045 & 0.047 & 0.025 & & & & & & & & & & & & & & & & \\
\hline Se. pessoni & 0.089 & 0.091 & 0.098 & 0.006 & & & & & & & & & & & & & & & \\
\hline Se. namo & 0.077 & 0.086 & 0.088 & 0.093 & 0.001 & & & & & & & & & & & & & & \\
\hline Se. kaltenbachi $\mathrm{n}$. sp. & 0.124 & 0.123 & 0.13 & 0.122 & 0.122 & - & & & & & & & & & & & & & \\
\hline Se. majungaensis & 0.097 & 0.113 & 0.108 & 0.112 & 0.106 & 0.124 & 0.004 & & & & & & & & & & & & \\
\hline Se. ozbeli n. sp. & 0.156 & 0.166 & 0.162 & 0.168 & 0.153 & 0.164 & 0.152 & - & & & & & & & & & & & \\
\hline Se. goodmani & 0.178 & 0.177 & 0.176 & 0.18 & 0.169 & 0.175 & 0.184 & 0.149 & 0.006 & & & & & & & & & & \\
\hline $\begin{array}{l}\text { Se. goodmani } \\
\quad \text { comorensis }\end{array}$ & 0.179 & 0.173 & 0.178 & 0.182 & 0.176 & 0.176 & 0.178 & 0.154 & 0.153 & 0.018 & & & & & & & & & \\
\hline Se. volfi $\mathrm{n}$. sp. & 0.153 & 0.157 & 0.158 & 0.141 & 0.138 & 0.163 & 0.139 & 0.162 & 0.192 & 0.193 & 0.015 & & & & & & & & \\
\hline Se. boironis & 0.118 & 0.122 & 0.124 & 0.129 & 0.105 & 0.16 & 0.12 & 0.157 & 0.164 & 0.168 & 0.134 & - & & & & & & & \\
\hline Se. huberti & 0.145 & 0.144 & 0.155 & 0.15 & 0.139 & 0.16 & 0.138 & 0.164 & 0.177 & 0.176 & 0.155 & 0.091 & 0.033 & & & & & & \\
\hline Grassomyia spp. & 0.159 & 0.155 & 0.162 & 0.156 & 0.144 & 0.174 & 0.156 & 0.179 & 0.19 & 0.191 & 0.155 & 0.131 & 0.136 & 0.1 & & & & & \\
\hline Ph. vincenti & 0.173 & 0.175 & 0.184 & 0.176 & 0.172 & 0.193 & 0.161 & 0.198 & 0.17 & 0.178 & 0.199 & 0.132 & 0.165 & 0.178 & - & & & & \\
\hline Ph. berentiensis & 0.19 & 0.181 & 0.19 & 0.192 & 0.182 & 0.212 & 0.186 & 0.23 & 0.212 & 0.214 & 0.199 & 0.153 & 0.169 & 0.162 & 0.148 & $\mathbf{0}$ & & & \\
\hline Ph. fontenillei & 0.188 & 0.183 & 0.195 & 0.195 & 0.18 & 0.214 & 175 & 0.24 & 0.213 & 0.219 & 0.212 & 0.151 & 0.164 & 0.16 & 0.144 & 0.032 & - & & \\
\hline Ph. vaomalalae & 0.182 & 0.178 & 0.184 & 0.191 & 0.17 & 0.203 & 0.158 & 0.224 & 0.202 & 0.198 & 0.2 & 0.142 & 0.161 & 0.159 & 0.148 & 0.043 & 0.032 & 0.012 & \\
\hline Ph. fertei & 0.173 & 0.169 & 0.18 & 0.168 & 0.189 & 0.214 & 0.175 & 0.213 & 0.216 & 0.217 & 0.198 & 0.144 & 0.16 & 0.168 & 0.14 & 0.145 & 0.144 & 0.135 & 0.006 \\
\hline
\end{tabular}




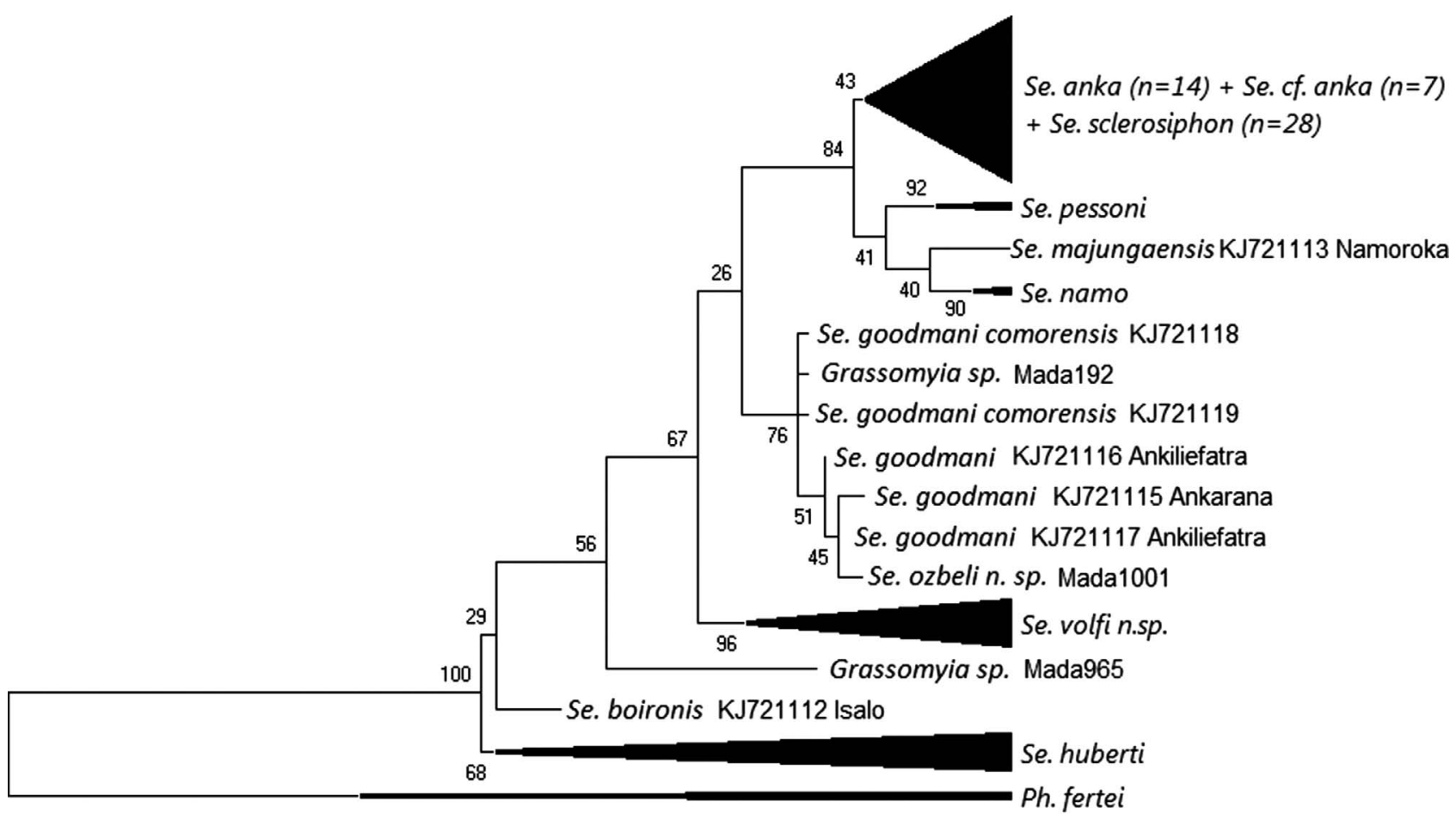

0.020

Figure 4. Maximum likelihood tree obtained from partial 28S rDNA sequences (D1 and D2 domains) based on the HKY85 model after rooting on Phlebotomus fertei. The tree with the highest log likelihood (-980.66) is shown. The percentage of trees in which the associated taxa clustered together is shown next to the branches. The tree is drawn to scale, with branch lengths measured in the number of substitutions per site. The analysis involved 126 nucleotide sequences.

sandfly recorded per trap). Phlebotomus fertei, Se. anka, Se. sclerosiphon, Se. volfi n. sp., and Se. ozbeli n. sp. were captured inside as well as outside of caves. Grassomyia spp. were not found in caves, which is in agreement with the biology of this genus [2]. The single specimen of Se. goodmani was obtained outside caves, whereas the single specimen of Se. kaltenbachi n. sp. was from within caves.

All sequences analyzed in the present study have been deposited in GenBank under the accession numbers MK465124-MK465180 and MK465182 (cyt B) and MK452276-MK452286 and MK452288-MK452340 (D1-D2 rDNA sequences), except for some specimens which could not be amplified or sequenced.

After rooting on available Madaphlebotomus sequences, maximum likelihood analysis carried out on a 620 bp database of cyt B sequences (Fig. 3) showed strong individualization of all species, except for Vattieromyia, and most of the specimens were grouped according to their morphological identification. Some specimens, however, doubtfully identified by morphology as Se. cf anka (MADA96, 199, 819, 876, 897, 898 and 1345) were branched together. Sergentomyia kaltenbachi $\mathrm{n}$. sp. was included in the Vattieromyia branch. Regarding the subgenus Rondanomyia, our specimen of Se. goodmani was grouped with sequences from this species deposited in GenBank and from Ankiliefatra and Namoroka. Its distribution now covers the North, the Centre and the south of Madagascar. The taxon Se. ozbeli n. sp. is the sister species of [Se. goodmani + Se. goodmani comorensis]. All the Sergentomyia volfi n. sp. specimens were strongly grouped together with high intraspecific variability of $1.6 \%$ (Table 3). Lastly, the genetic distance between the two sequenced Grassomyia specimens of more than $10 \%$ clearly suggests that they do not belong to the same species.

Maximum likelihood analysis carried out on a 520 bp database of D1-D2 rDNA sequences (Fig. 4) showed little variability between most of the specimens referred to as both Se. sclerosiphon and $\mathrm{Se}$. anka, with the exception of specimens labelled MADA95, 199, 876, 893, 897, and 1345, which were on a separate branch. Sergentomyia majungaensis, an ungrouped Sergentomyia, was included in the Vattieromyia clade.

Only one Grassomyia specimen was well isolated.

Within the Rondanomyia subgenus, some variability was noted between Se. goodmani and Se. goodmani comorensis. The six variable nucleotide positions could explain the mixing of the both taxa. Sergentomyia ozbeli n. sp. was mixed with these taxa.

All specimens morphologically identified as Se. volfi $\mathrm{n}$. sp. were included in a well-defined clade.

Genetic distances calculated on rDNA sequences between and within taxa are provided in Table 4. 


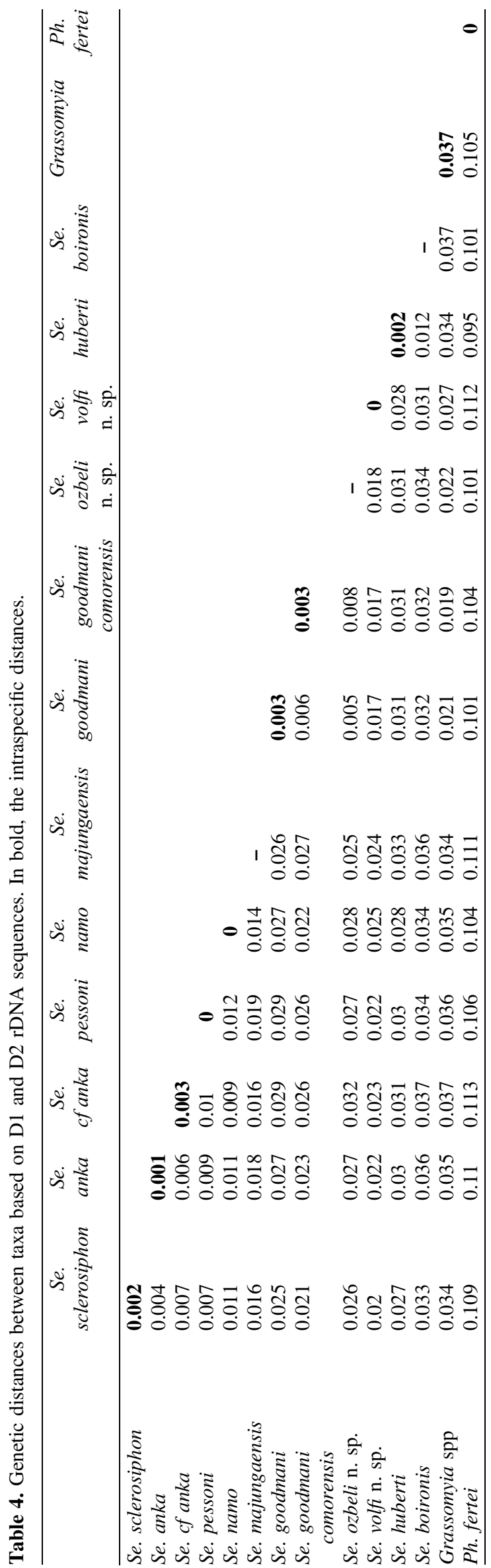

The analysis of cytochrome b sequences enabled us to highlight a clade close to that of Sergentomyia anka. Morphometric analysis of the sandflies involved ( 31 females) by means of multifactorial approaches (principal component analysis and hierarchical clustering) was then carried out. Twelve head parameters were investigated: flagellomeres 1-3 (AIII, AIV, and AV), labrum (Lb), maxillary palpal segments (P1-P5), and first, second, and third row of vertical teeth (D1R, D2R, and D3R).

Principal component analysis yielded a variability of more than $37 \%$ for the F1 axis, 25\% for F2, and $9 \%$ for $\mathrm{F} 3$ (Table 5). Parameters with the highest contribution (more than 5\%) for the F1 axis were flagellomeres AIII, AIV, and AV, palpal segments $\mathrm{P} 1$ and $\mathrm{P} 4$, and the second row of vertical teeth (D2R). Labrum (Lb) represented $13.9 \%$ of the variability along the F2 axis, along with palpal segments (P3-P5), and the first and third row of vertical teeth (D1R and D3R) (Table 6). Overall, the different parameters investigated accounted for more than $81 \%$ of the variability of the $\mathrm{F} 1$ axis and more than $89 \%$ of the variability of the F2 axis. Figures 5-7 display the clustering of the 31 sandflies studied.

Hierarchical clustering analysis was able to find slightly more homogeneous groups of Sergentomyia (Fig. 7). It also confirmed that the four sandfly specimens which formed a clade belong to the $S e$. anka species.

\section{Sergentomyia (Ranavalonomyia) volfi Depaquit, Blavier \& Laroche n. sp.}

urn:lsid:zoobank.org:act:80C255F3-9A66-4A10-880A6933641FBFBB

Genus: Sergentomyia França \& Parrot 1920

Subgenus: Ranavalonomyia subg. nov. Depaquit, Blavier \& Laroche (type-species: Se. volfi n. sp.)

Authorship: note that the authors of the new taxon are different from the authors of this paper; Article 50.1 and Recommendation 50A of International Code of Zoological Nomenclature [21].

Etymology: the species is dedicated to our Czech colleague Petr Volf.

Type-locality: tsingy of Ankarana, Madagascar.

Type-specimens: holotype female (MADA1011) and five paratypes (two males labelled MADA825 and MADA899 and three females labelled MADA829, MADA895 and MADA901) deposited in the Muséum National d'Histoire Naturelle, Paris, France (MNHN).

\section{Female (Figures 8 and 9)}

A total of 16 specimens were examined. Counts and measurements indicated in the description are those of the holotype MADA1011.

\section{Head}

Occiput with two narrow lines of well individualized setae. On the line above the eyes, two greater insertions of setae on each side. Clypeus $81 \mu \mathrm{m}$ long, $63 \mu \mathrm{m}$ wide, with about 30 setae randomly distributed. Eyes $188 / 107 \mu \mathrm{m}$ with about 100 facets. 
Table 5. Principal component analysis results (raw values).

\begin{tabular}{|c|c|c|c|c|c|c|c|c|c|c|c|c|}
\hline & F1 & F2 & F3 & $\mathrm{F} 4$ & F5 & F6 & F7 & F8 & F9 & F10 & F11 & F12 \\
\hline & 4.54 & 201 & 1.11 & 088 & 0.728 & 0.56 & 0.44 & 0.34 & 0.19 & 0.143 & 0.030 & 0.008 \\
\hline $\mathrm{y}(\%)$ & 37.891 & 25.090 & 9.266 & 7.3 & & & & & & & 0.254 & 0.069 \\
\hline Cumulative & 37.891 & 62.981 & 72.248 & 79.602 & 85.668 & 90.363 & 94.029 & 96.880 & 98.488 & 99.677 & 99.931 & 100 \\
\hline
\end{tabular}

Table 6. Parameter contribution (\%) to the total variability (highest contributions displayed in bold).

\begin{tabular}{lrrr}
\hline Variable & \multicolumn{1}{c}{ F1 } & \multicolumn{1}{c}{ F2 } & \multicolumn{1}{c}{ F3 } \\
\hline A3 & $\mathbf{1 7 . 5 4 9}$ & 0.125 & $\mathbf{1 0 . 6 0 6}$ \\
A4 & $\mathbf{1 8 . 2 3 2}$ & 1.890 & 6.423 \\
A5 & $\mathbf{1 8 . 6 2 2}$ & 0.620 & 6.682 \\
Lb & 7.008 & $\mathbf{1 3 . 9 5 0}$ & 6.880 \\
P1 & $\mathbf{8 . 7 9 1}$ & 3.409 & $\mathbf{1 6 . 4 1 0}$ \\
P2 & 2.125 & 4.287 & $\mathbf{1 1 . 9 2 8}$ \\
P3 & 4.771 & $\mathbf{1 7 . 9 9 6}$ & 1.985 \\
P4 & $\mathbf{8 . 4 2 4}$ & $\mathbf{1 2 . 6 3 3}$ & 0.341 \\
P5 & 0.075 & $\mathbf{1 3 . 8 2 1}$ & $\mathbf{2 4 . 7 0 2}$ \\
D1R & 0.003 & $\mathbf{2 0 . 3 4 3}$ & $\mathbf{8 . 3 0 5}$ \\
D2R & $\mathbf{1 0 . 2 1 8}$ & 0.120 & 3.491 \\
D3R & 4.183 & $\mathbf{1 0 . 8 0 7}$ & 2.248 \\
& $81.8 \%$ & $89.6 \%$ & $72 \%$ \\
\hline
\end{tabular}

Interantennal suture incomplete. Interocular suture not reaching the interantennal one.

Flagellomeres. Flagellomere 1 longer than $\mathrm{f} 2+\mathrm{f} 3$. Absence of ascoid on $\mathrm{f} 1$ and $\mathrm{f} 2$. Ascoidal formula: $2 / \mathrm{f} 3-\mathrm{f} 13$. One distal papilla on $\mathrm{f} 1$ and $\mathrm{f} 2$. Absence of papilla from $\mathrm{f} 3 \mathrm{to} \mathrm{f} 11$. Three papillae on flagellomeres 12-14. Absence of simple setae on flagellomeres $\mathrm{f} 1 \mathrm{-f} 3$. One simple seta on flagellomeres f4-f8, f10, and f12. Two simple setae on f9, f11, and f13. About 20 simple setae on f14. Palpi showing a very wide P3. Palpal formula: 1-5. Presence of many Newstead's sensilla on P3 (74 on the holotype) implanted basally. Absence of Newstead's sensilla on P2. Presence of one distal spiniform seta on P3 and of five spiniform setae on P4.

Labrum-epipharynx $187 \mu \mathrm{m}$ long. Hypopharynx with three small apical teeth on each side of the salivary canal. Maxillary lacinia with about 10 large distal external teeth and about 20 internal ones. Labium showing an open labial suture. Cibarium with 24 clear and palissadic teeth organized along a horizontal line. There are about ten dot-like vertical teeth in front, irregularly disposed along a horizontal line. The pigment patch is pale, triangular with an anterior expansion giving it an overall aspect of russula. Well-armed pharynx on its posterior quarter with long pigmented teeth oriented posteriorly and towards the center.

\section{Cervix}

Presence of two cervical and two ventro-cervical sensilla on each side.

\section{Thorax}

Length: $556 \mu \mathrm{m}$, sclerites medium brown, absence of postalar setae, absence of paratergital setae, absence of proepimeral setae, absence of upper anepisternal setae, absence of lower anepisternal setae, absence of anepimeral setae, absence of metepisternal setae, absence of metepimeral setae, presence of setae on the anterior region of the katepisternum. Absence of suture between metepisternum and katepimeron. Metafurca mounted laterally; it is not possible to see clearly whether the vertical arms are joined by a membrane or not.

\section{Wing}

Length: $1930 \mu \mathrm{m}$; width: $510 \mu \mathrm{m}$. R5 = $1340 \mu \mathrm{m}$; alpha $(=\mathrm{R} 2)=356 \mu \mathrm{m}$; beta $(=\mathrm{R} 2+3)=390 \mu \mathrm{m}$; gamma $(=\mathrm{R} 2+3+4)=327 \mu \mathrm{m}$; delta $=349 \mu \mathrm{m}$; pi $=142 \mu \mathrm{m}$; epsilon $(=\mathrm{R} 3)=500 \mu \mathrm{m}$; theta $(=\mathrm{R} 4)=998 \mu \mathrm{m}$.

\section{Legs}

Anterior leg: $\operatorname{coxa}=284 \mu \mathrm{m}$; femur $=691 \mu \mathrm{m}$; tibia $=813 \mu \mathrm{m}$; tarsomere $\mathrm{i}=455 \mu \mathrm{m}$; sum of tii, tiii, tiv, $\mathrm{tv}=592 \mu \mathrm{m}$. Median leg: $\operatorname{coxa}=277 \mu \mathrm{m}$; femur $=696 \mu \mathrm{m}$; tibia $=949 \mu \mathrm{m}$; tarsomere $\mathrm{i}=537 \mu \mathrm{m}$; other tarsomeres broken. Posterior leg: $\operatorname{coxa}=305 \mu \mathrm{m}$; femur $=765 \mu \mathrm{m}$; tibia $=1099 \mu \mathrm{m}$; tarsomere $\mathrm{i}=626 \mu \mathrm{m}$; sum of tii, tiii, tiv, tv $=720 \mu \mathrm{m}$. Absence of spines on the metafemur. One verticil of two spines in the middle and one distal spine of the metatarsomere iii was observed on the paratype MADA1010.

\section{Abdomen}

Setae randomly distributed on tergites ii-v. Tergite VIII with 14 setae on each side.

Tergite IX without protuberance. Cerci $=155 \mu \mathrm{m}$. Setae not observed on sternite $\mathrm{X}$.

\section{Genitalia}

The appearance of the spermathecae in the Marc-André liquid is very different after dehydration for their mounting in Euparal $^{\circledR}$. In the Marc-André liquid, spermathecae appear elongated, with rather thick walls, and are not sclerotized. The body is unsegmented but covered with many transverse parallel folds giving it a striated appearance. The terminal knob, which carries four and five canaliculi terminates in a bulge, is slightly embedded in the distal part of the body with a cloudlike frill around it. After mounting in Euparal ${ }^{\circledR}$, the spermatheca systematically retracts to a rectangular shape and folds tend to fade. Individual ducts are thin and narrow, smooth and nonsclerotized. They come together to form a short common duct opening at the level of the genital chamber.

The furca has wide and well-developed lateral arms and a stem widening towards the apex. The frame of the genital chamber consists of many small spines arranged more or less regularly and aligned in a few rows.

\section{Male (Figures 10 and 11)}

A total of 14 specimens have been examined. Counts and measurements indicated in the description are those of the paratype MADA825. 


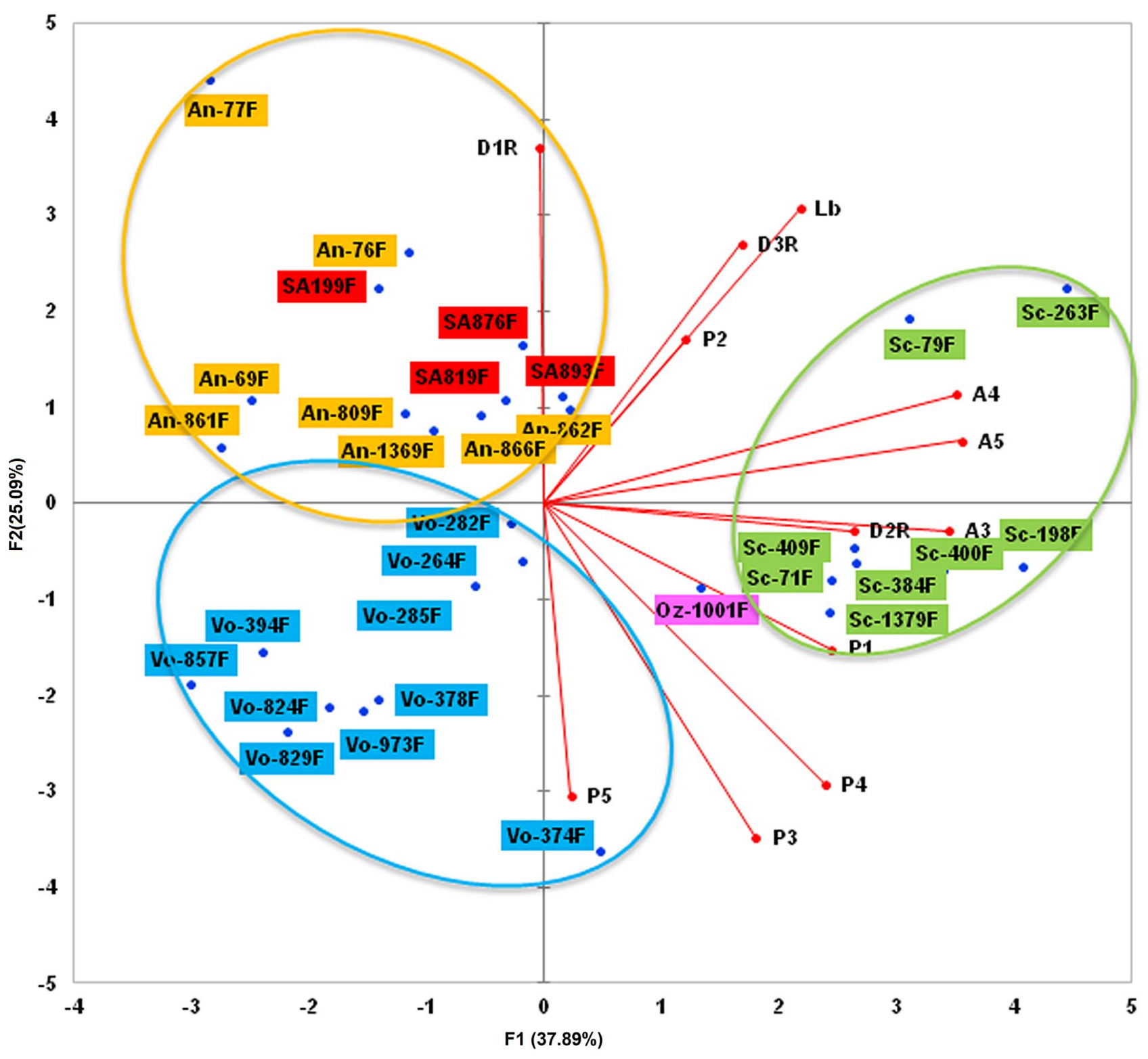

- variables observations

Figure 5. First factorial plan ( $\mathrm{F} 1$ and $\mathrm{F} 2$ axes). $\mathrm{Sc}=$ Se. sclerosiphon; $\mathrm{An}=S e$. anka; $\mathrm{SA}=S e$. cf. anka; Vo = Se. volfi $\mathrm{n} . \mathrm{sp} . ; \mathrm{Oz}=S e$. ozbeli n. sp. $($ all specimens $=+$ ).

\section{Head}

Occiput bearing two well individualized lines of setae. On the infero-lateral line, we can notice two larger insertions on each side. Clypeus bearing 24 setae randomly distributed. Eyes measuring $150 \mu \mathrm{m}$ high on $85 \mu \mathrm{m}$ wide, with about 70 facets. Incomplete interocular sutures.

Flagellomeres. Antennal formula: 1/f3 - f13. Absence of ascoid on segments f1 and f2 (=AIII and AIV). One terminal papilla on flagellomeres $\mathrm{f} 1$ and $\mathrm{f} 2$. One papilla on $\mathrm{f} 11$ and three papillae on segments f12-f14. Absence of simple setae on segments $\mathrm{f} 1-\mathrm{f} 5$ as well as $\mathrm{f} 12$ and $\mathrm{f} 13$. One simple seta from f6 to f8. Two simple setae from f9 to f11 and a dozen on f14. Palpal formula: 1-5. A dozen of Newstead's sensilla grouped, implanted in the basal quarter of the article. Absence of
Newstead's sensilla on P2. One long spiniform seta distally implanted on P3 and four regularly implanted on P4.

Labrum-epipharynx $140 \mu \mathrm{m}$ long. Labial suture closed or sometimes very slightly opened. Cibarium armed with ten packs of three to four very small vertical teeth grouped on an irregular line more or less horizontal. In front, some vertical teeth barely observable. Lack of pigment patch. Pharynx armed on its posterior quarter with small pointed teeth oriented backwards, organized along more or less concentric lines.

\section{Cervix}

Presence of two cervical setae and two ventro-cervical on each side. 


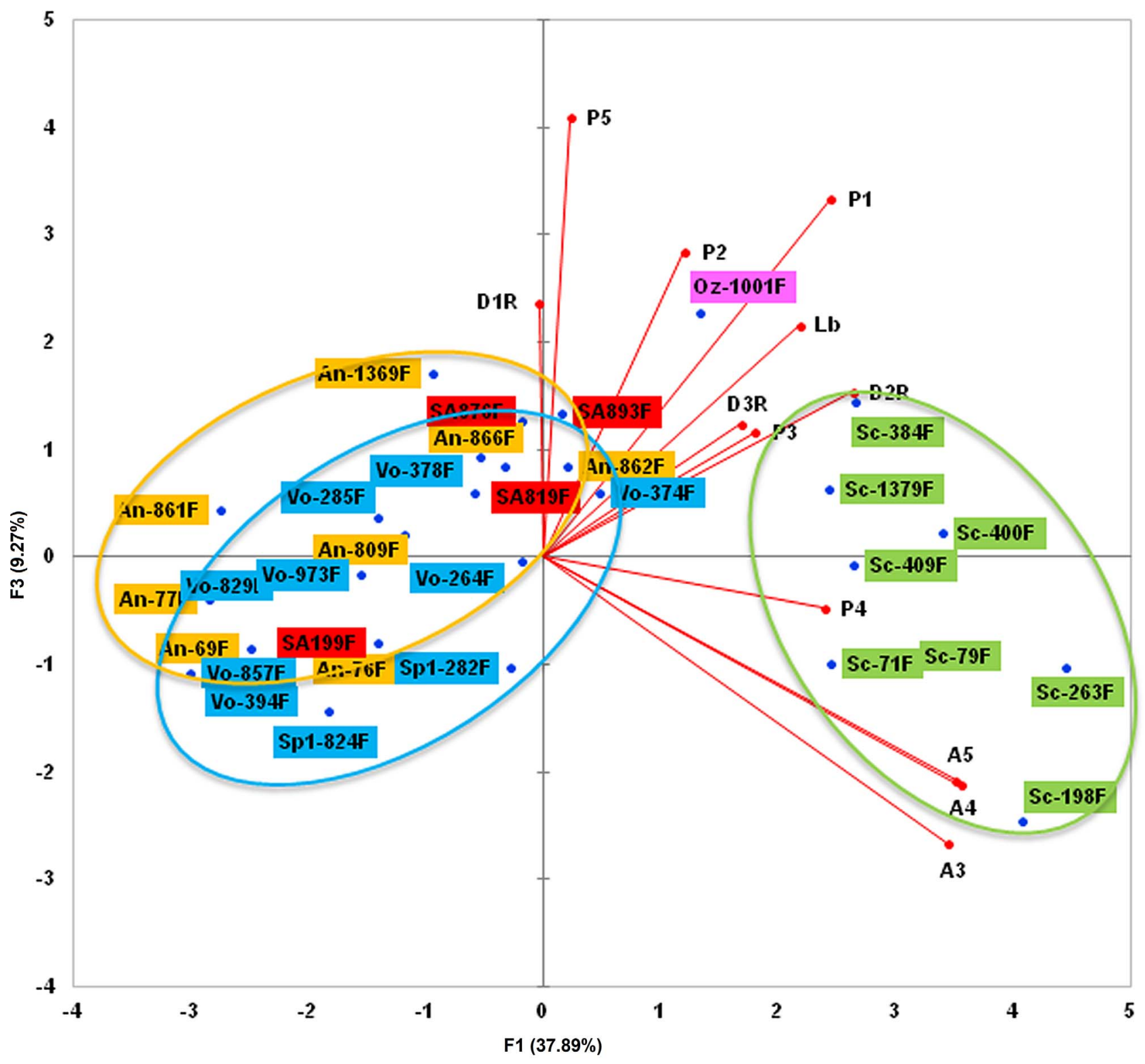

\section{- variables $\quad$ observations}

Figure 6. Second factorial plan ( $\mathrm{F} 1$ and $\mathrm{F} 3$ axes). $\mathrm{Sc}=S e$. sclerosiphon; $\mathrm{An}=S e$. anka; $\mathrm{SA}=S e$. cf. anka; $\mathrm{Vo}=S e . v o l f i \mathrm{n} . \mathrm{sp} . ; \mathrm{Oz}=S e$. ozbeli $\mathrm{n}$. sp. (all specimens $=$ १).

\section{Thorax}

Light brown sclerites, absence of post-alar setae, absence of proepimeral setae, absence of superior or inferior setae on the mesanepisternum, absence of anepimeral setae, absence of setae on the metepisternum, absence of metepimeral setae, presence of setae in the anterior area of the katepisternum. Absence of suture between the metepisternum and the katepimeron. Metafurca mounted laterally; it is not possible to see clearly whether the vertical arms are joined by a membrane or not.

\section{Wing}

Length: $1280 \mu \mathrm{m}$; width: $308 \mu \mathrm{m} . \quad \mathrm{R} 5=931 \mu \mathrm{m}$; alpha $\left(=\mathrm{R}_{2}\right)=118 \mu \mathrm{m}$; beta $\left(=\mathrm{R}_{2+3}\right)=253 \mu \mathrm{m}$; gamma
$\left(=\mathrm{R}_{2+3+4}\right)=302 \mu \mathrm{m}$; delta $=-8 \mu \mathrm{m}$; pi $=50 \mu \mathrm{m}$; epsilon $\left(=\mathrm{R}_{3}\right)=231 \mu \mathrm{m}$; theta $\left(=\mathrm{R}_{4}\right)=602 \mu \mathrm{m}$.

\section{Legs}

Anterior leg: $\operatorname{coxa}=256 \mu \mathrm{m}$; femur $=520 \mu \mathrm{m}$; tibia $=594 \mu \mathrm{m}$; tarsomere $\mathrm{i}=318 \mu \mathrm{m}$; sum of the tarsomeres tii, tiii, tiv and tv $=434 \mu \mathrm{m}$. Median leg: $\operatorname{coxa}=250 \mu \mathrm{m}$; femur $=543 \mu \mathrm{m}$; tibia $=734 \mu \mathrm{m}$; tarsomere $\mathrm{i}=375 \mu \mathrm{m}$; sum of the tarsomeres tii, tiii, tiv and tv $=505 \mu \mathrm{m}$. Posterior leg: coxa $=270 \mu \mathrm{m}$; femur $=580 \mu \mathrm{m}$; tibia $=885 \mu \mathrm{m}$; tarsomere $\mathrm{i}=473 \mu \mathrm{m}$; sum of the tarsomeres tii, tiii, tiv and $\mathrm{tv}=564 \mu \mathrm{m}$. Absence of spines on the metafemur. Two setae implanted in the middle of the metatarsomere iii and one implanted distally. 


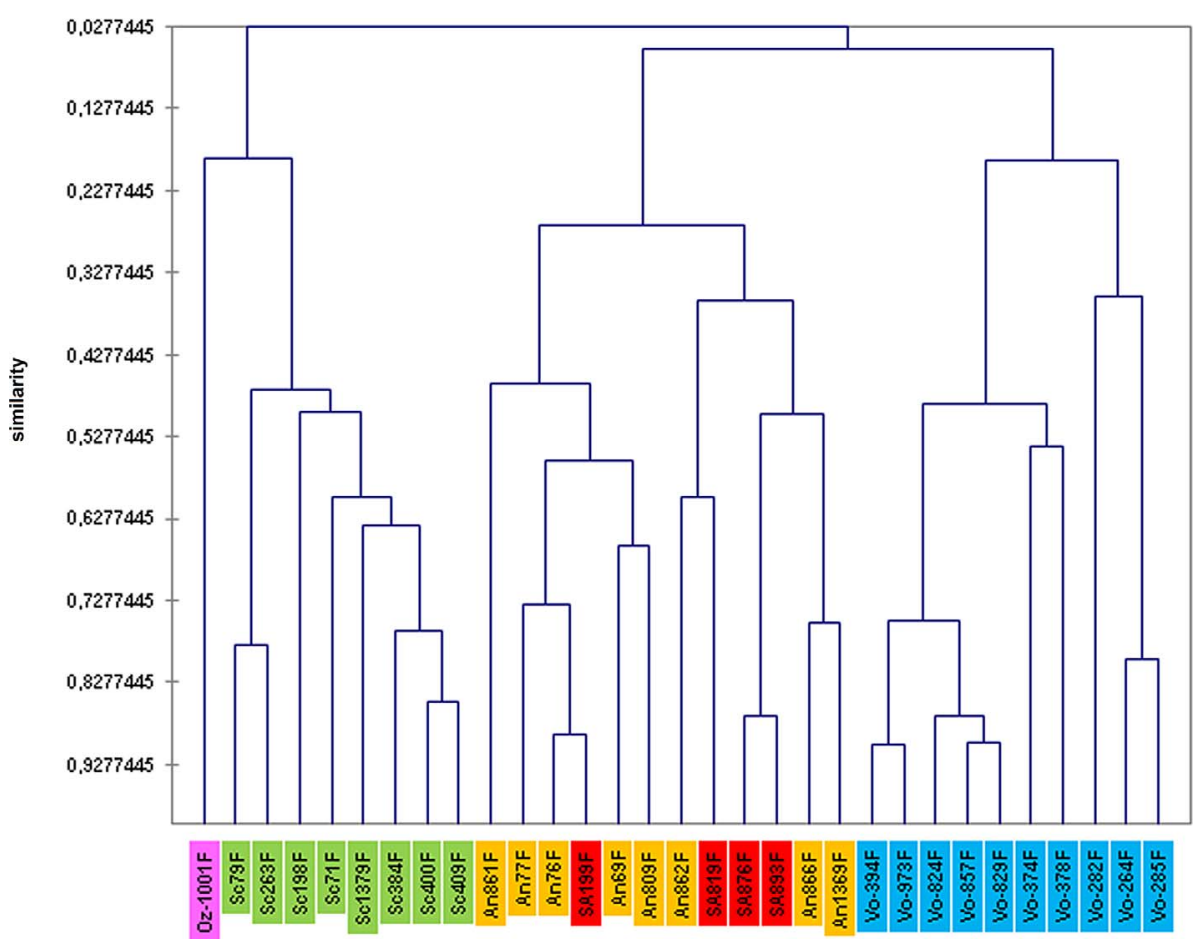

Figure 7. Hierarchical clustering based on morphometrical characters of females belonging to the following species Sc = Se. sclerosiphon; $\mathrm{An}=$ Se. anka; $\mathrm{SA}=$ Se. cf. anka $; \mathrm{Vo}=$ Se. volfi $\mathrm{n} . \mathrm{sp} . ; \mathrm{Oz}=$ Se. ozbeli $\mathrm{n} . \mathrm{sp}$.

\section{Abdomen}

Setae distributed randomly over ii-v. Absence of papilla on the tergites ii-vii.

\section{Genitalia}

Absence of abdominal sclerotised rods. Gonocoxite carrying a tuft of about twenty internal setae. Absence of basal lobe. Gonostyle bearing four thick, curved terminal spines (or two terminal and two subterminal spines). Accessory spine implanted very distally. Simple paramere, slightly curved at its apex with a vestiture occupying the inner face of the distal half. Parameral sheath straight, finger-like, narrowing gradually from the proximal end to the distal end which is rounded. Striated aedeagal ducts, pointed at their apex. Sperm pump with a long thin piston. Epandrial lobes shorter than the gonocoxite. Cerci $=100 \mu \mathrm{m}$.

\section{Ranavalonomyia Depaquit, Blavier \& Laroche subg. nov.}

urn:lsid:zoobank.org:act:D7CCB6F7-3AF5-43B7-AEAFCADE0CDC7384

Both sexes: labial suture open; absence of ascoid on flagellomeres $\mathrm{f} 1$ and $\mathrm{f} 2$ (=AIII and AIV); presence of an apical fringe on the top of $\mathrm{f} 1-\mathrm{f} 6$ and absence of setae on the following sclerites of the thorax: proepimeron, anepisternum, anepimeron, katepimeron, metepisternum and metepimeron. Female: third palpal segment particularly wide, with a large number of basal Newstead's sensilla; spermathecae slightly wrinkled, without sclerification.

Type-species: Sergentomyia (Ranavalonomyia) volfi Depaquit, Blavier \& Laroche n. sp.
Etymology: the subgenus is dedicated to Ranavalona III, the last Queen of Madagascar.

\section{Sergentomyia (Rondanomyia) ozbeli Depaquit, Blavier \& Randrianambinintsoa n. sp.}

urn:lsid:zoobank.org:act:D96B70E2-9B0C-42FA-AC25-

\section{BB2D5DB4C15}

Genus: Sergentomyia França \& Parrot 1920

Subgenus: Rondanomyia Theodor, 1958

Authorship: note that the authors of the new taxon are different from the authors of this paper; Article 50.1 and Recommendation 50A of International Code of Zoological Nomenclature [21].

Etymology: the species is dedicated to our Turkish colleague Yusuf Ozbel.

Type-locality: tsingy of Ankarana, Madagascar.

Type-specimens: holotype female (MADA1001) and one paratype female (mounted in toto on a slide with seven other sandflies) deposited in the Muséum National d'Histoire Naturelle, Paris, France (MNHN).

The measurements indicated below are those related to the holotype labelled MADAIT13 except for the legs, measured on the paratype MADA1001.

Number of specimens examined $=3$.

\section{Female (Figures 12 and 13)}

\section{Head}

Occiput with two narrow lines of setae well individualized. On the line above the eyes, two larger insertions of setae on 

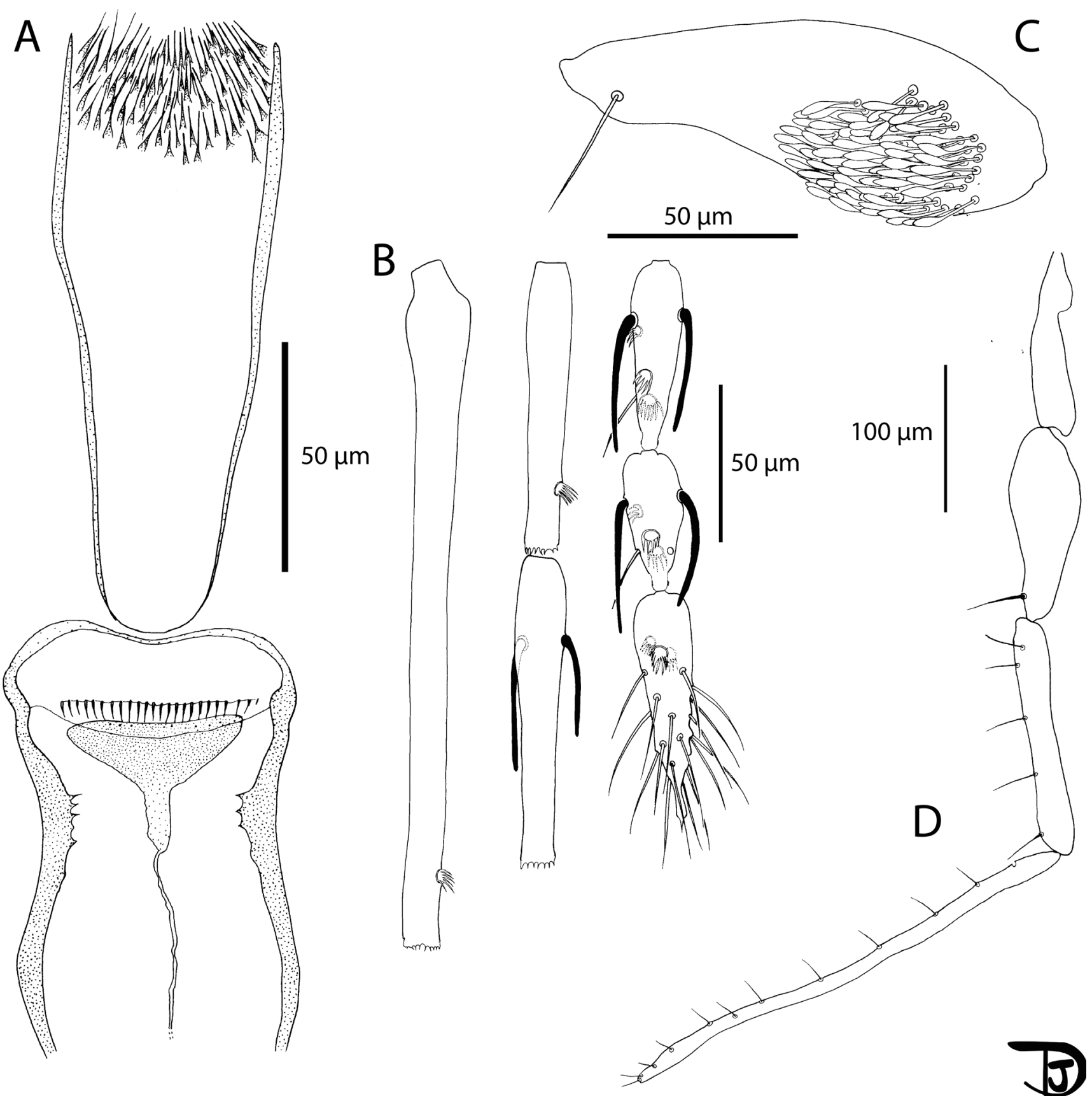

Figure 8. Sergentomyia (Ranavalonomyia) volfi n. sp. female holotype (MADA1011). (A) pharynx and cibarium, (B) flagellomeres 1, 2, 3, $12,13 \& 14$, (C) third palpal segment, (D) palp.

each side. Clypeus $110 \mu \mathrm{m}$ long, $184 \mu \mathrm{m}$ wide, with setae randomly distributed. Eyes 396/210 $\mu$ m with more than 130 facets. Interantennal suture not complete. Interocular sutures thick.

Flagellomere 1 as long as $\mathrm{f} 2+\mathrm{f} 3$. Flagellomeres exhibiting two ascoids from $\mathrm{f} 1$ to $\mathrm{f} 13$. The internal and external ascoids on f1 are implanted at the same level; On the holotype, one terminal papilla on f1 and f2; one median papilla on f9-f11. Three papillae on f12-f14. On the holotype, no simple setae have been observed from $\mathrm{f} 1$ to $\mathrm{f} 6$; two from $\mathrm{f} 7$ to $\mathrm{f} 11$; three on f12 and f13; about ten simple setae and one spine on f14. Palpal formula: 1-5. About 50 basal Newstead's sensillae on p3. No
Newstead's sensilla on p2. One distal spiniform seta on p3 and 5 on 4 , regularly implanted.

Labrum-epipharynx $197 \mu \mathrm{m}$ long with lateral spines at the top; Hypopharynx with very small apical teeth. Maxillary lacinia with about 25 internal teeth and 10 external teeth at the top; Labium exhibiting an open labial suture. Cibarium with a line of about 20 colorless posterior teeth. The central ones are more or less identical to the lateral ones, except for a few vertical teeth on each side. One row of anterior vertical teeth of dot-like appearance. The central ones are bigger than the lateral ones. In front of the latter row, there is a dark wavy line, parallel to the 


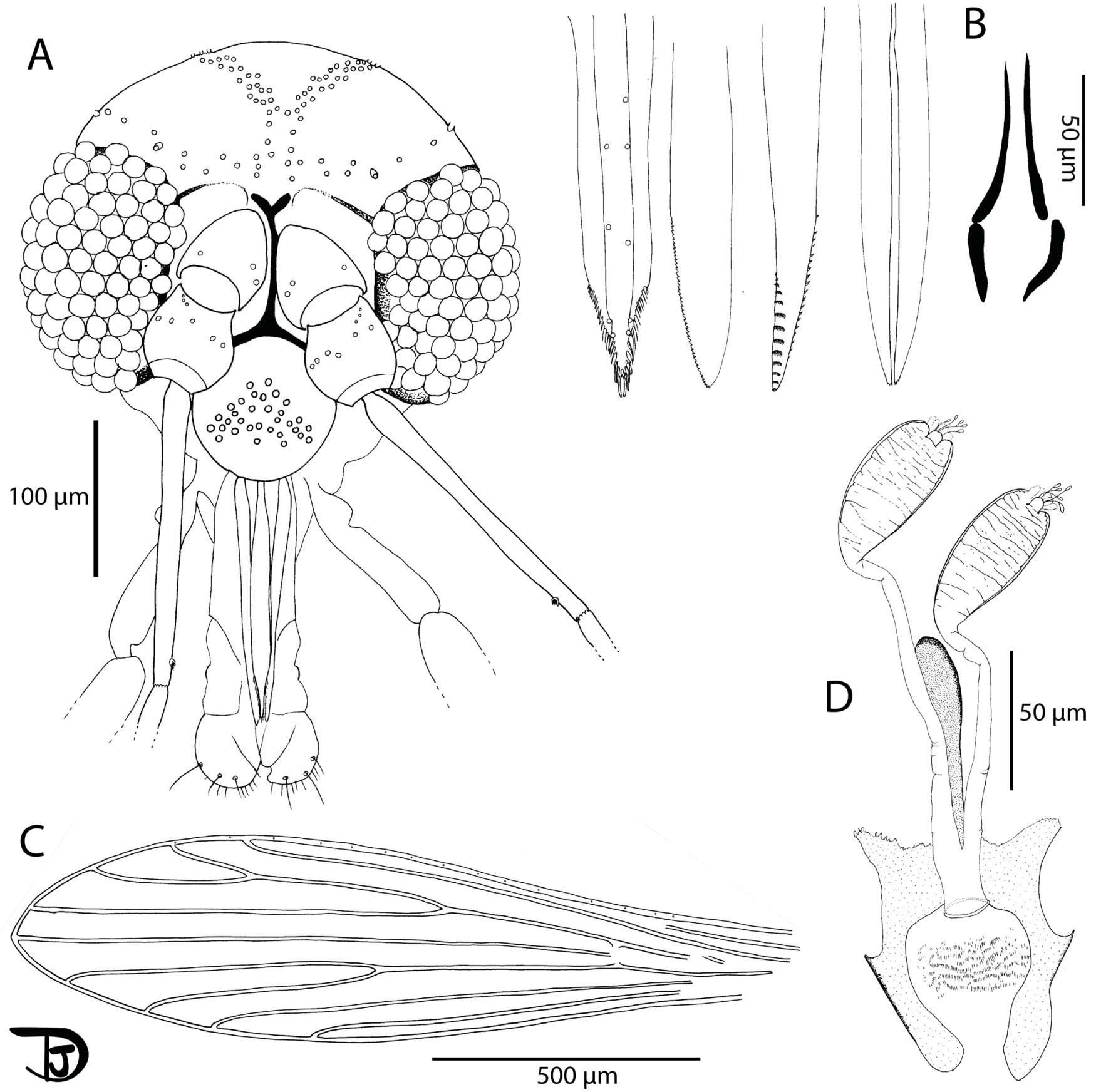

Figure 9. Sergentomyia (Ranavalonomyia) volfi n. sp. female. (A) head (paratype MADA895), (B) mouth parts: labrum-epipharynx, mandible, maxilla, hypopharynx \& labial furca, respectively (paratype MADA901), (C) wing (paratype MADA829), (D) spermathecae, not smooth, showing wrinkles, and genital furca (paratype MADA901).

lines of teeth, completely traversing the sclerotized area (=pigment patch) exhibiting a posterior expansion.

Pharynx armed with small dot-like teeth arranged along more or less concentric lines.

\section{Cervix}

Two cervical sensilla on each side. Ventro-cervical sensilla not observed.

\section{Thorax}

$590 \mu \mathrm{m}$ long, dark sclerites, presence of post-alar setae, absence of proepimeral setae, absence of upper anepisternal setae, absence of lower anepisternal setae, absence of anepimeral setae, absence of metepisternal setae, absence of metepimeral setae, presence of setae on the anterior region of the katepisternum. Absence of suture between metepisternum and katepimeron. Metafurca mounted laterally; it is not possible to see clearly whether the vertical arms are joined by a membrane or not. 


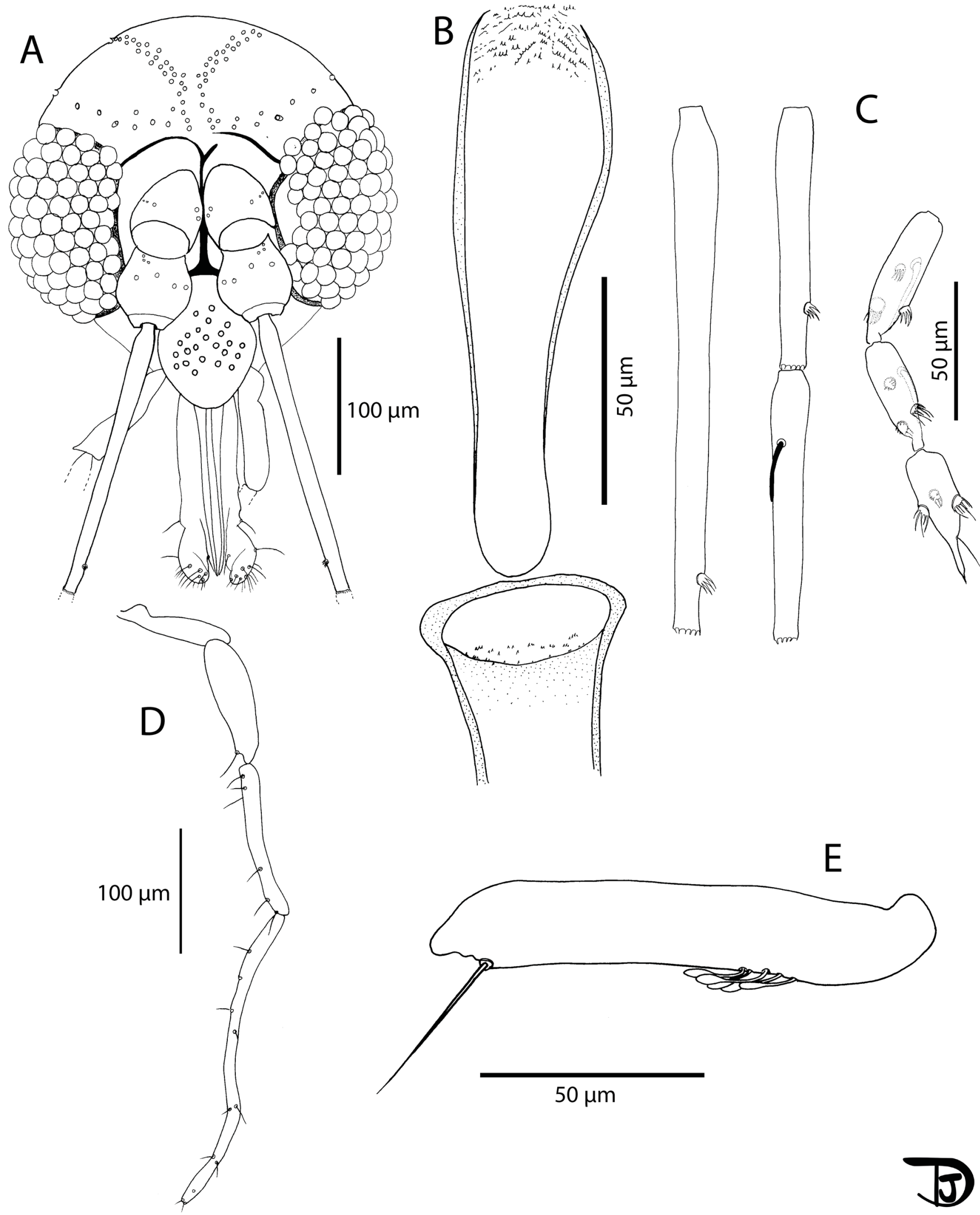

Figure 10. Sergentomyia (Ranavalonomyia) volfi n. sp. male. (A) head (paratype MADA825), (B) pharynx and cibarium (paratype MADA825), (C) flagellomeres 1, 2, 3, 12, 13 \& 14 (paratype MADA899), (D) third palpal segment (paratype MADA825), (E) palp (paratype MADA899). 

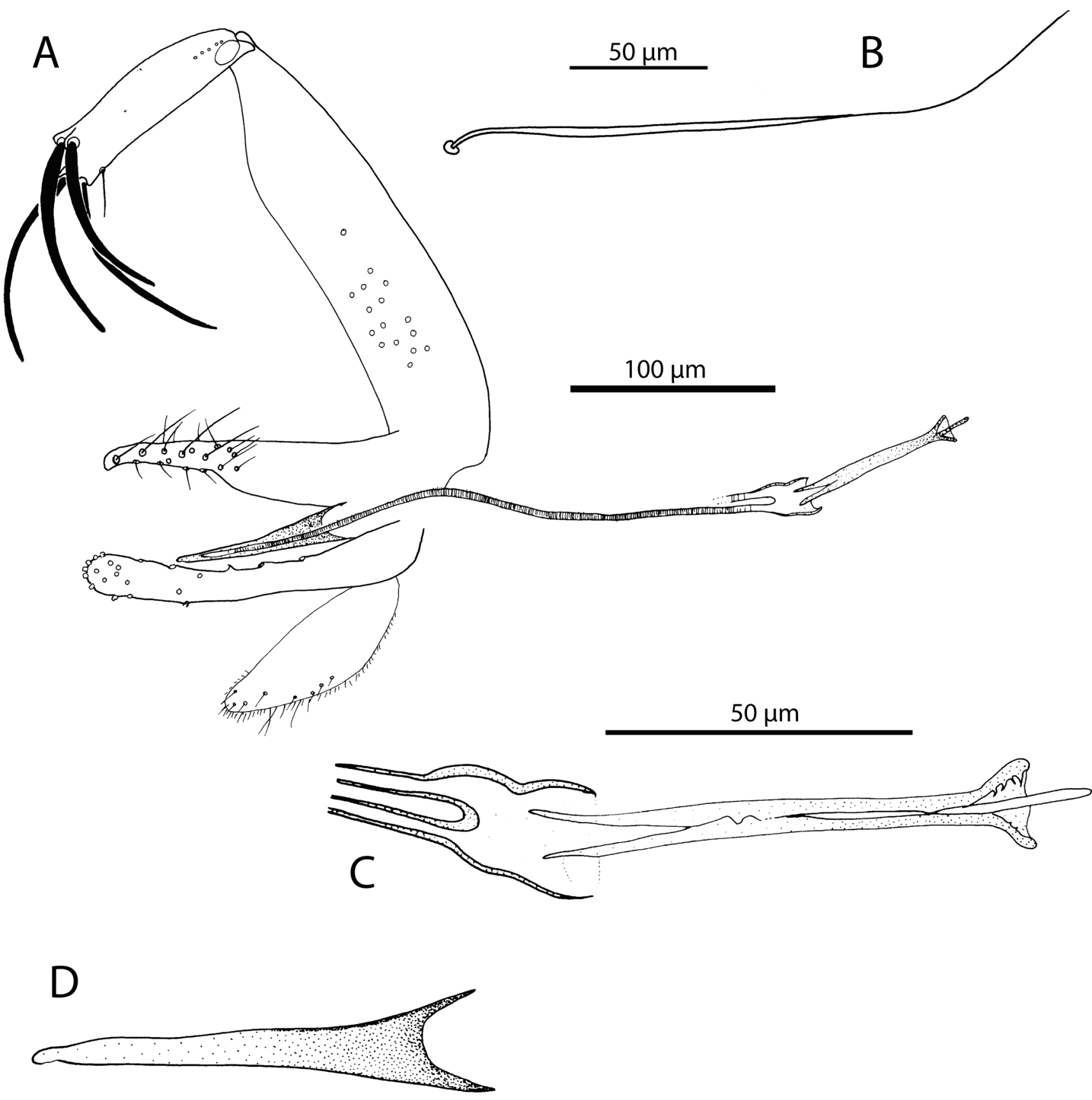

$50 \mu \mathrm{m}$

E

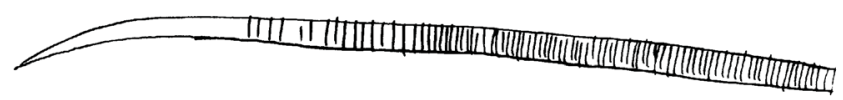

$50 \mu \mathrm{m}$

Figure 11. Sergentomyia (Ranavalonomyia) volfi n. sp. male (paratype MADA825). (A) genitalia, (B) detail of a ventral coxal seta, (C) sperm pump, (D) parameral sheath, (E) top of the aedeagal ducts. 


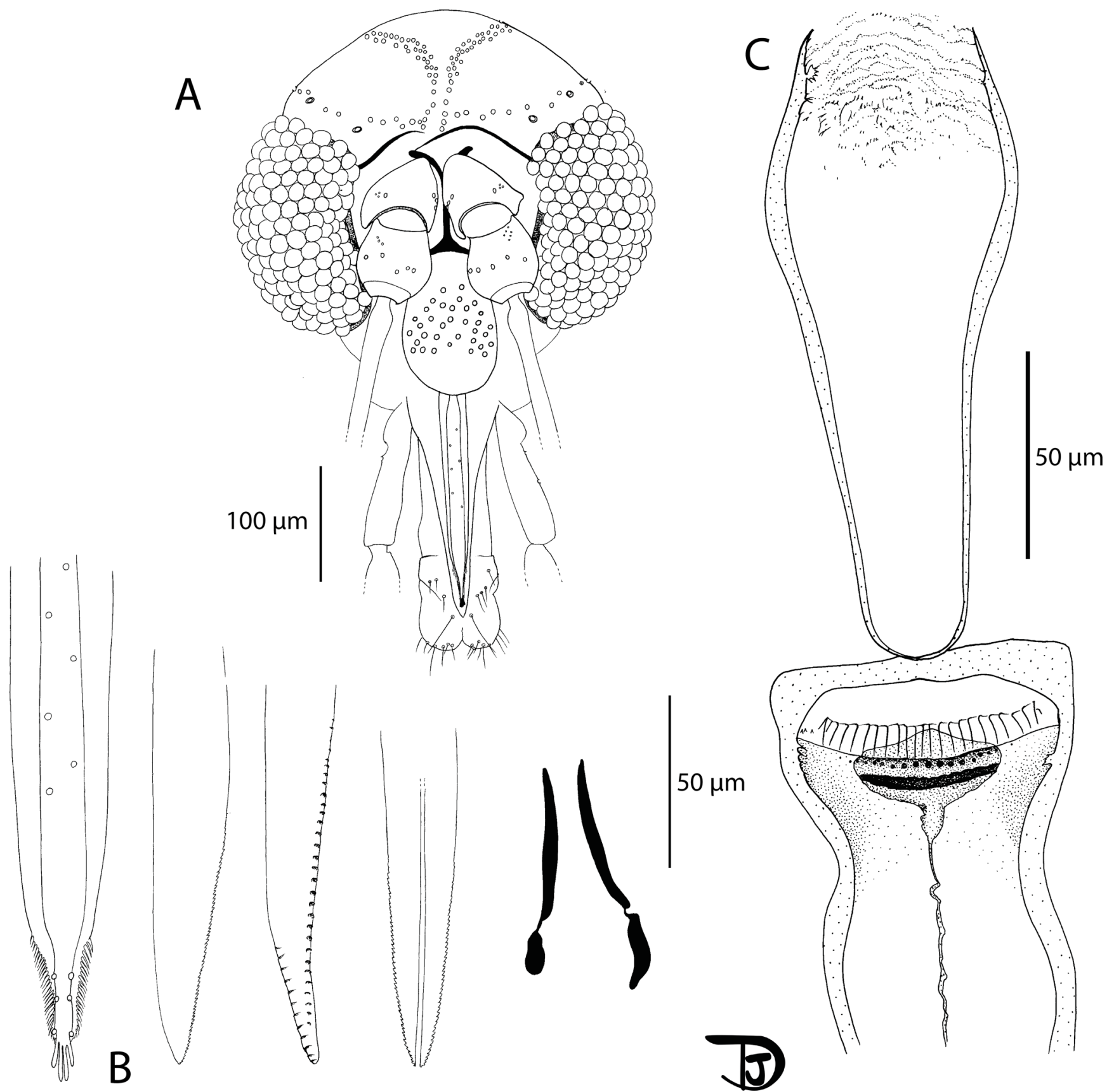

Figure 12. Sergentomyia (Rondanomyia) ozbeli n. sp. female (holotype MADA1001). (A) head, (B) mouth parts: labrum-epipharynx, mandible, maxilla, hypopharynx \& labial furca, respectively, (C) pharynx and cibarium.

\section{Wing}

Length: $1824 \mu \mathrm{m}$; width: $500 \mu \mathrm{m} . \mathrm{R} 5=1292 \mu \mathrm{m}$; alpha $\left(=\mathrm{R}_{2}\right)=332 \mu \mathrm{m}$; beta $\left(=\mathrm{R}_{2+3}\right)=390 \mu \mathrm{m}$; gamma $\left(=\mathrm{R}_{2+3+4}\right)=264 \mu \mathrm{m}$; delta $=184 \mu \mathrm{m} ;$ pi $=245 \mu \mathrm{m}$; epsilon $\left(=\mathrm{R}_{3}\right)=390 \mu \mathrm{m}$; theta $\left(=\mathrm{R}_{4}\right)=984 \mu \mathrm{m}$.

\section{Legs}

Anterior leg: $\operatorname{coxa}=282 \mu \mathrm{m}$; femur $=690 \mu \mathrm{m}$; tibia $=735 \mu \mathrm{m}$; tarsomere $\mathrm{i}=411 \mu \mathrm{m}$; sum of tii, tiii, tiv, $\mathrm{tv}=630 \mu \mathrm{m}$. Median leg: coxa $=292 \mu \mathrm{m}$; femur $=698 \mu \mathrm{m}$; tibia $=845 \mu \mathrm{m}$; tarsomere $\mathrm{i}=495 \mu \mathrm{m}$; sum of tii, tiii, tiv, $\mathrm{tv}=660 \mu \mathrm{m}$. Posterior leg: coxa $=327 \mu \mathrm{m}$; femur $=783 \mu \mathrm{m}$; tibia $=1054 \mu \mathrm{m}$; tarsomere $\mathrm{i}=557 \mu \mathrm{m}$; sum of tii, tiii, tiv, $\mathrm{tv}=713 \mu \mathrm{m}$. Absence of spines on the metafemur. One verticil of two spines on the metatarsomere iii.

\section{Abdomen}

Setae randomly implanted on tergites ii-v. Presence of about 20 setae on tergite VIII. Absence of protuberance on the tergite IX. Setae not observed on the sternite X.

\section{Genitalia}

Oval spermatheca exhibiting throughout its length many internal spines rosebush-like in lateral view and dot-like 


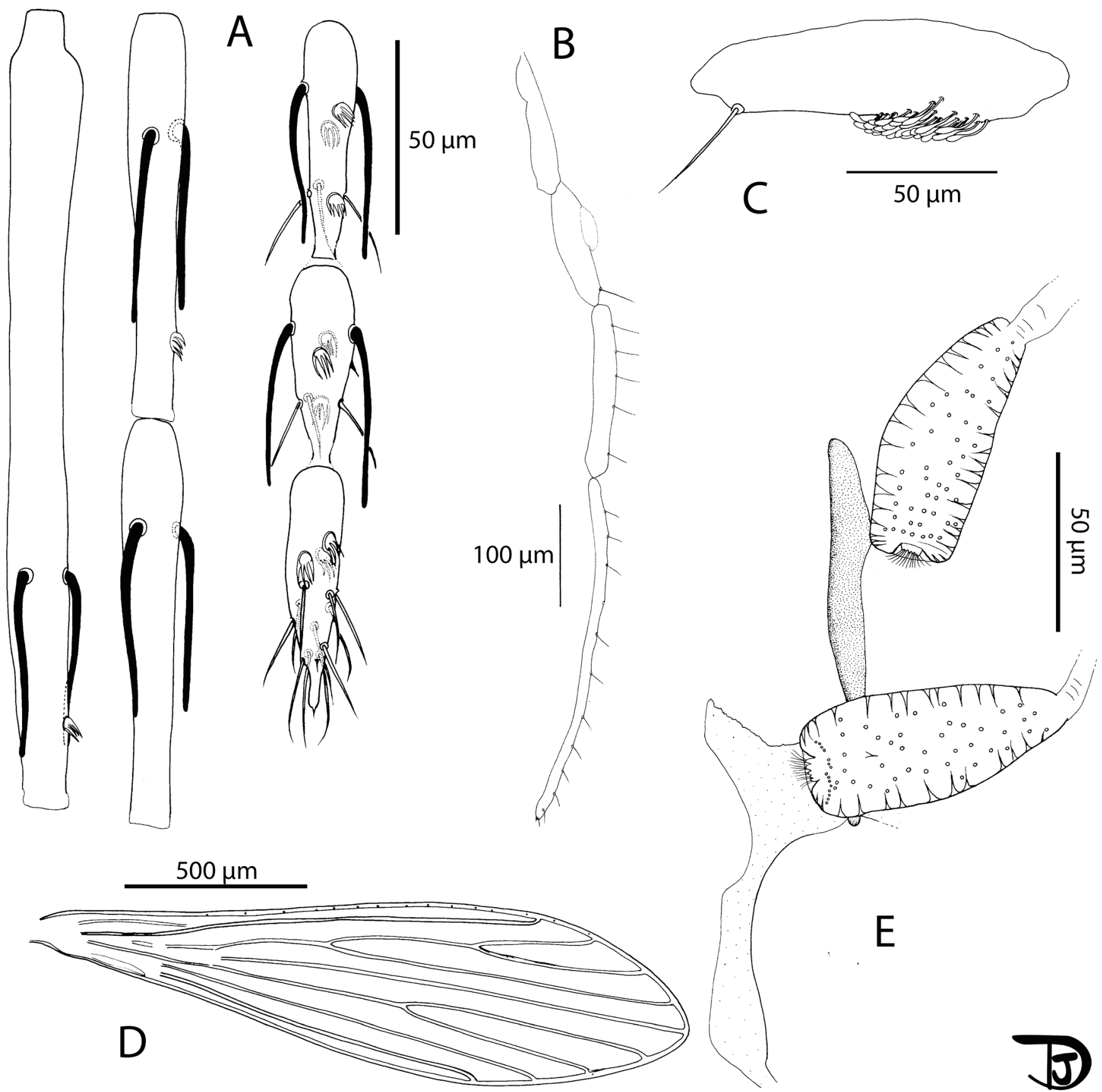

Figure 13. Sergentomyia (Rondanomyia) ozbeli n. sp. female (holotype MADA1001). (A) flagellomeres 1, 2, 3, 12, 13, and 14; pharynx and cibarium, (B) palp, (C) third palpal segment, (D) wing, (E) spermathecae and genital furca.

in apical or proximal view. Short and flattened terminal knob, invaginated in the spermatheca, bearing about 10 canaliculi. Furca partly hidden but nevertheless showing a long and narrow stem. Genital chamber observed but impossible to draw. Distal part of the individual ducts of the spermathecae without any sclerotization nor striation. Basal part of the spermathecal ducts not observed on the holotype. On one paratype, observation of a common duct. Cerci = $166 / 69 \mu \mathrm{m}$.

\section{Sergentomyia (Riouxomyia) kaltenbachi Depaquit, Blavier \& Randrianambinintsoa n. sp.}

urn:lsid:zoobank.org:act:B8FE04DD-CF80-4DDC-B9AB-

\section{E12DE64180A}

Genus: Sergentomyia França \& Parrot 1920

Subgenus: Riouxomyia subg. nov. Depaquit, Blavier \& Randrianambinintsoa (type-species: Se. kaltenbachi n. sp.)

Authorship: note that the authors of the new taxon are different from the authors of this paper; Article 50.1 and 
Recommendation 50A of International Code of Zoological Nomenclature [21].

Etymology: the species is dedicated to our French colleague Matthieu Kaltenbach.

Type-locality: tsingy of Ankarana, Madagascar.

Type-specimen: holotype female (MADA728) deposited in the Muséum National d'Histoire Naturelle, Paris, France (MNHN).

The measurements indicated below are those related to the holotype. Some organs broken during the catching, storage or mounting process and impossible to observe.

\section{Female (Figures 14 and 15) \\ Head}

Occiput with two narrow lines of setae well individualized. Clypeus $105 \mu \mathrm{m}$ long, $80 \mu \mathrm{m}$ wide, with setae randomly distributed. Eyes 186/86 $\mu \mathrm{m}$ well developed including about 100 facets. Interantennal and interocular suture complete.

Flagellomere 1 longer than $\mathrm{f} 2+\mathrm{f} 3$. Two ascoids from $\mathrm{f} 1$ to f13. The internal ascoid is implanted approximatively at the same level as the external one. One terminal papilla on f1 and $\mathrm{f} 2$. No papilla from $\mathrm{f} 3$ to $\mathrm{f} 9$. One papilla on $\mathrm{f} 10$ and $\mathrm{f} 11$. Three papillae on $\mathrm{f} 12$ and four on $\mathrm{f} 13$ and $\mathrm{f} 14$. No simple setae observed from f1 to f12; three on $\mathrm{f} 13$ and eight on f14; Palpal formula: 1, (2, 3), 4, 5. About 15 basal Newstead's sensilla on p3. No Newstead's on p2. One distal spiniform seta on p3 and seven on $\mathrm{p} 4$, regularly implanted.

Mouth parts difficult to observe due to a lateral orientation of the holotype. Labrum $195 \mu \mathrm{m}$ long. Maxillary lacinia with about 25 internal and 25 external teeth. Labial furca not observed; Cibarium with a horizontal row of 52 teeth arranged in palisade. Lateral ones are shorter than the others. We observe just below 21 small punctate vertical teeth linked to them. In the middle of the pigment patch, there is a transverse line of 19 vertical teeth of dot-like appearance. The pigment patch is decomposed into a rather pigmented, sausage-shaped posterior part, crossing the entire cibarium. In the anterior part, there is a little pigmented triangle. The pharynx is armed at its posterior third by many strong teeth oriented backwards.

\section{Cervix}

Cervical sensilla and ventro-cervical sensilla not observed.

\section{Thorax}

About $460 \mu \mathrm{m}$ long, dark sclerites, absence of post-alar setae, paratergital setae on the pleural sclerites not observed, absence of proepimeral setae, absence of upper anepisternal setae, absence of lower anepisternal setae, absence of anepimeral setae, absence of metepisternal setae, absence of metepimeral setae, presence of setae on the anterior region of the katepisternum. Suture between metepisternum and katepimeron not observed. Metafurca mounted laterally; it is not possible to see clearly whether the vertical arms are joined by a membrane or not.

\section{Wing}

Length: $1888 \mu \mathrm{m}$; width: $482 \mu \mathrm{m}$. R5 $=1298 \mu \mathrm{m}$; alpha $(=\mathrm{R} 2)=268 \mu \mathrm{m}$; beta $(=\mathrm{R} 2+3)=375 \mu \mathrm{m}$; gamma
$(=\mathrm{R} 2+3+4)=327 \mu \mathrm{m}$; delta $=90 \mu \mathrm{m} ; \mathrm{pi}=165 \mu \mathrm{m}$; epsilon $(=\mathrm{R} 3)=445 \mu \mathrm{m}$; theta $(=\mathrm{R} 4)=921 \mu \mathrm{m}$.

\section{Legs}

Anterior leg: $\operatorname{coxa}=329 \mu \mathrm{m}$; femur $=664 \mu \mathrm{m}$; tibia $=728 \mu \mathrm{m}$; tarsomere $\mathrm{i}=357 \mu \mathrm{m}$; sum of tii, tiii, tiv, tv $=603 \mu \mathrm{m}$. Median leg: $\operatorname{coxa}=297 \mu \mathrm{m}$; femur $=648 \mu \mathrm{m}$; tibia $=888 \mu \mathrm{m}$; tarsomere $\mathrm{i}=437 \mu \mathrm{m}$; sum of tii, tiii, tiv, $\mathrm{tv}=650 \mu \mathrm{m}$. Posterior leg: $\operatorname{coxa}=307 \mu \mathrm{m}$; femur $=728 \mu \mathrm{m}$; tibia $=1044 \mu \mathrm{m}$; tarsomere $\mathrm{i}=532 \mu \mathrm{m}$; sum of tii, tiii, tiv, tv $=724 \mu \mathrm{m}$. Absence of spines on the metafemur. One verticil of spines in the middle of the metatarsomere iii.

\section{Abdomen}

Setae on tergites ii-v not observed. Tergite VIII, IX and sternite IX not observed.

\section{Genitalia}

Body of the spermathecae finely wrinkled with an enlargement at the base. One spur at the top, close to the knob. The terminal knob is embedded in the body and carries about 15 canaliculi. Spermathecal ducts thin and wide with a basal common duct as long as the individual ones. After mounting, the spermathecal ducts were not observable and the aspect of the spermathecal body changed. Cerci not observed.

\section{Riouxomyia Depaquit, Blavier \& Randrianambinintsoa subg. nov.}

urn:Isid:zoobank.org:act:60D5FC67-4656-4EBF-866E1EB677E97BE8

Based on female: presence of two ascoids on flagellomeres f1-f13 (=AIII-AXV); absence of setae on the following sclerites of the thorax: proepimeron, anepisternum, anepimeron, katepimeron, metepisternum and metepimeron; spermathecae finely wrinkled with an enlargement at the base and one spur at the top, close to the knob.

Type-species: Sergentomyia (Riouxomyia) kaltenbachi Depaquit, Blavier \& Randrianambinintsoa n. sp.

Etymology: the subgenus is dedicated to the memory of our colleague Jean-Antoine Rioux.

\section{Discussion}

The research carried out in Ankarana involved the collection of 723 phlebotomine sandflies. The material studied included nine species, this richness being the highest documented at any single location in Madagascar. This inventory confirms that tsingy areas are favorable environments for phlebotomine sandflies. Caves associated with constant temperatures and humidity are presumed to be excellent resting places as compared to other areas [35].

Phlebotomus fertei is the only species of the genus Phlebotomus recorded at Ankarana. It is relatively abundant (120 specimens representing about $17 \%$ of those captured), and remains the most widespread and studied Phlebotomus in 

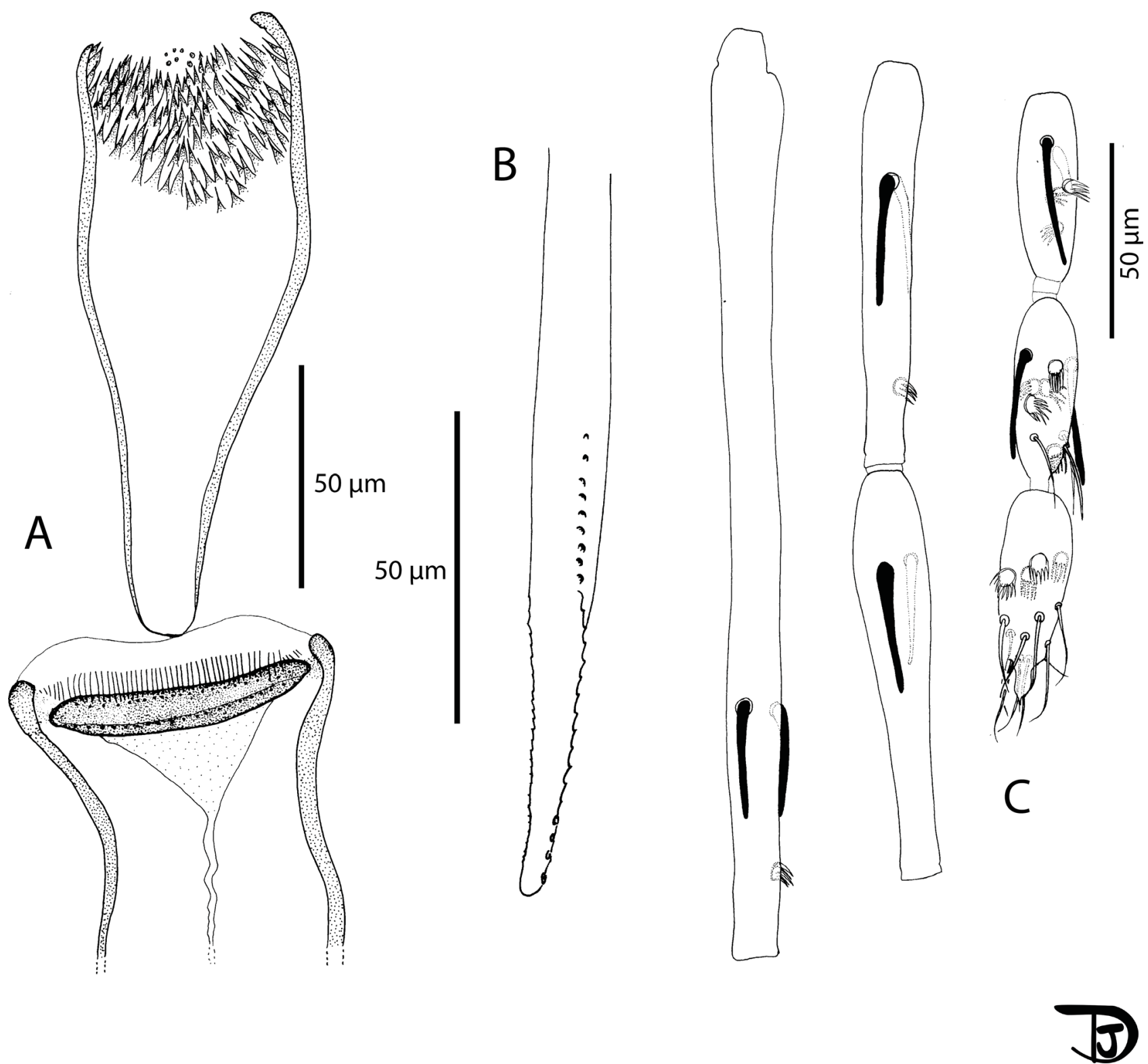

Figure 14. Sergentomyia (Riouxomyia) kaltenbachi n. sp. female (holotype MADA728). (A) pharynx and cibarium, (B) maxilla, (C) flagellomeres 1, 2, 3, 12, 13 and 14 .

Madagascar. The specimens from Ankarana are morphologically similar to the type series from Bemaraha, also a tsingy habitat.

In the material we collected in Ankarana, genus Grassomyia was presented by four specimens, three males and one female. Considering that the systematics of this group are probably among the most complicated regarding Phlebotomine sandflies, we did not go into considerable detail. Males are much more difficult to identify than females and out of four specimens of genus Grassomyia captured, only one was a female. Although the only female specimen might belong to Gr. madagascariensis, due to the presence of 40 cibarial teeth, the species identification of the males remains doubtful. This genus is poorly represented at Ankarana and is much more frequent in open landscapes elsewhere in the country. The record of Gr. squamipleuris in Madagascar [34] calls for confirmation, as the type species is from continental Africa (Khartoum, Sudan) and all other phlebotomine sandflies on Madagascar are endemic.

In this study, we focused mainly on the genus Sergentomyia, which was the most abundant in our study representing over $82 \%$ of the captures, despite a controversial role in the transmission of Leishmania spp. [28]. The species most frequently caught belonged to the subgenus Vattieromyia which accounted for more than $75 \%$ of the individuals identified. This subgenus consists of four previously described species: Se. sclerosiphon and Se. anka described from Ankarana [12], Se. namo described from Namoroka [12], and Se. pessoni described from the Comoros Archipelago [31]. Males and females have already been described for the first two species. For two other species, only females are known. As has frequently been observed in the genus Sergentomyia, the species diagnosis is simpler for 


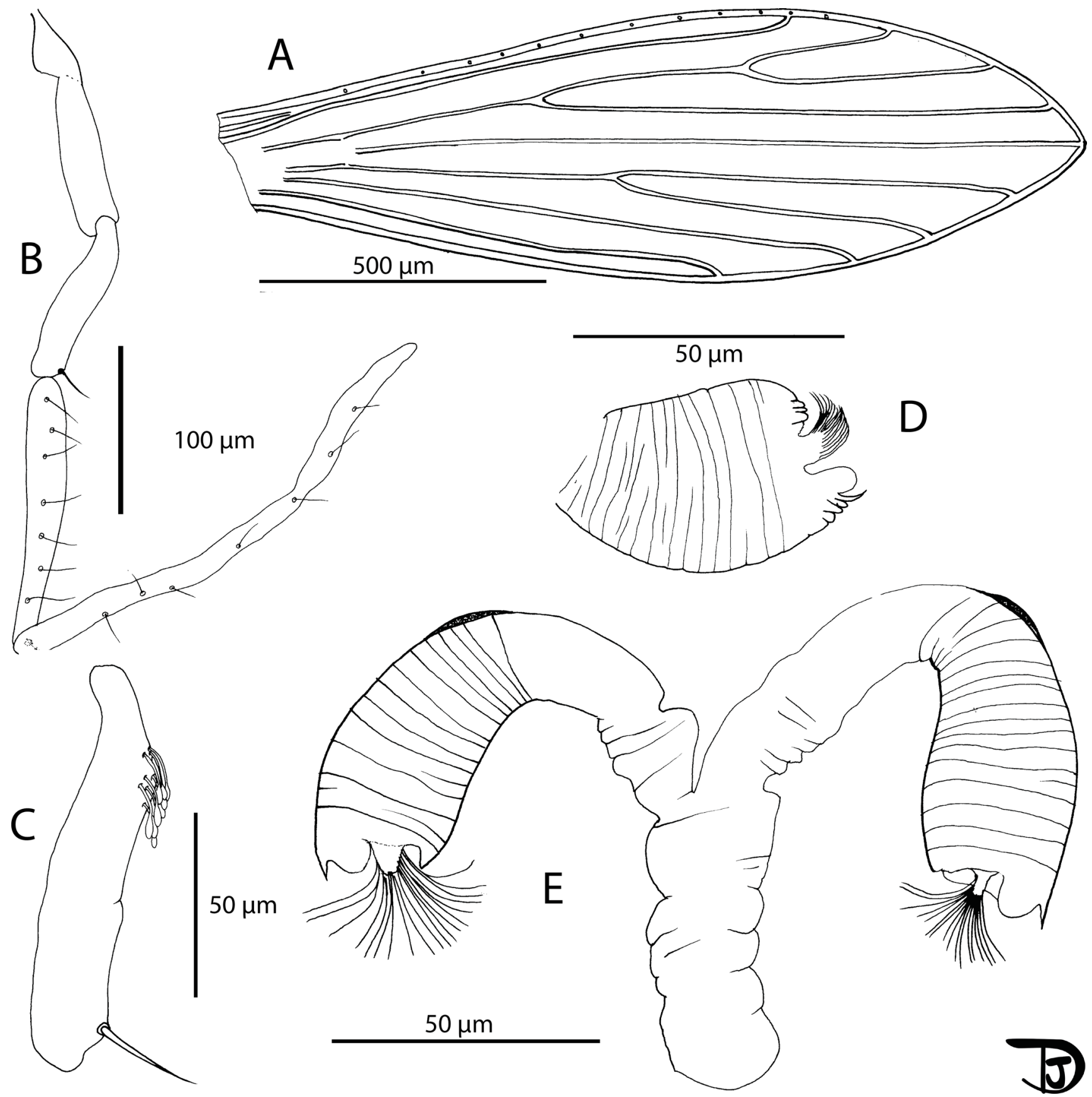

Figure 15. Sergentomyia (Riouxomyia) kaltenbachi n. sp. female (holotype MADA728). (A) wing, (B) palp, (C) third palpal segment, (D) spermathecae after mounting, (E) spermathecae drawn in Marc-André.

females than for males. The latter are sometimes morphologically very similar, which has complicated their identification, especially for Vattieromyia. Indeed, the position of the accessory spine on the gonostyle is difficult to evaluate and there is some overlap in the length measurements of the flagellomeres. Moreover, the cibarial armature of males is discrete and depends on the condition of the specimen, including how it is positioned on the slide, and the use of phase contrast microscopy (Fig. 16).
We identified the Ankarana material based on comparison with type specimens. In many cases, the spermathecae are the primary character for subgeneric classification of sandflies, but their use at the species level is limited. It is often easier to identify species based on the teeth of the cibarium. For Se. anka, the original description is based on the presence of a posterior row of 35-43 teeth (average: 38 ). The central ones are much longer than the lateral ones and are curved. Based on a larger sample than in the original description, we found 
(A)

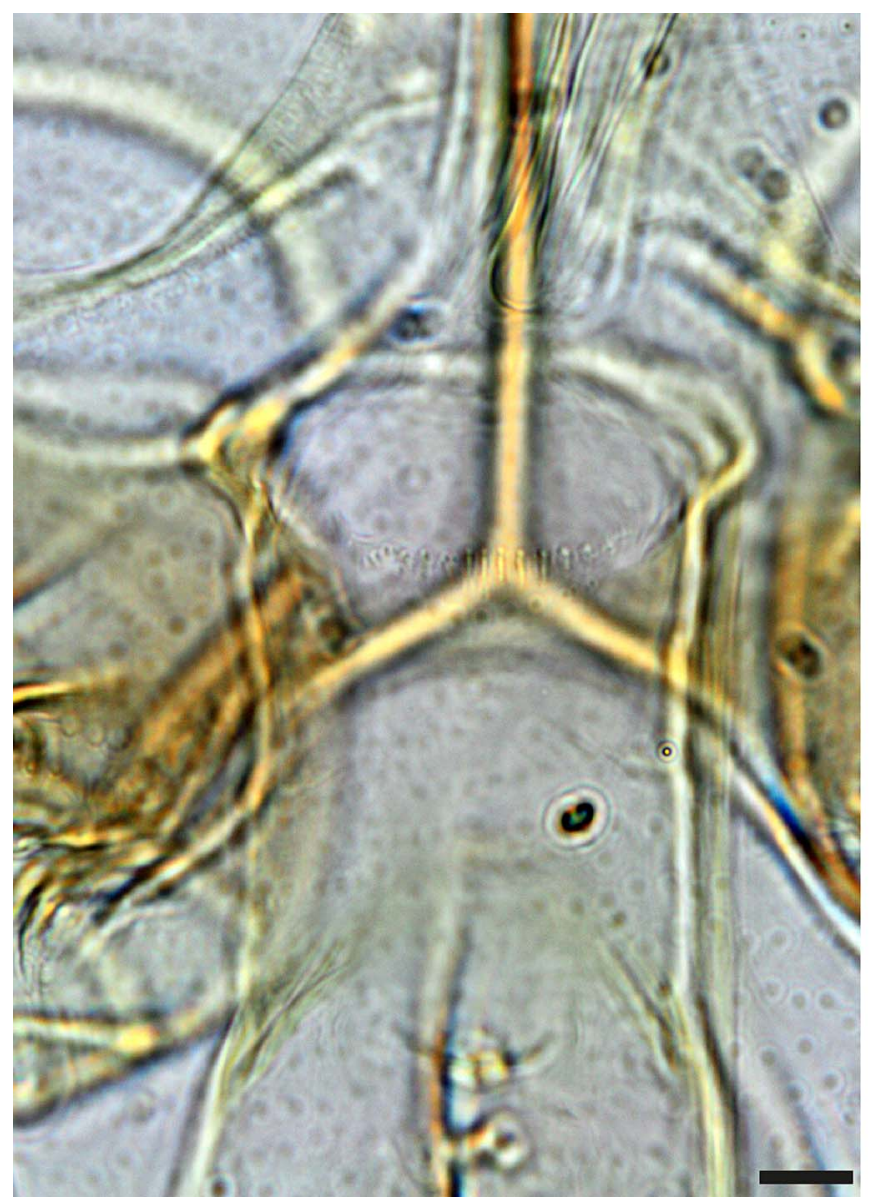

(B)

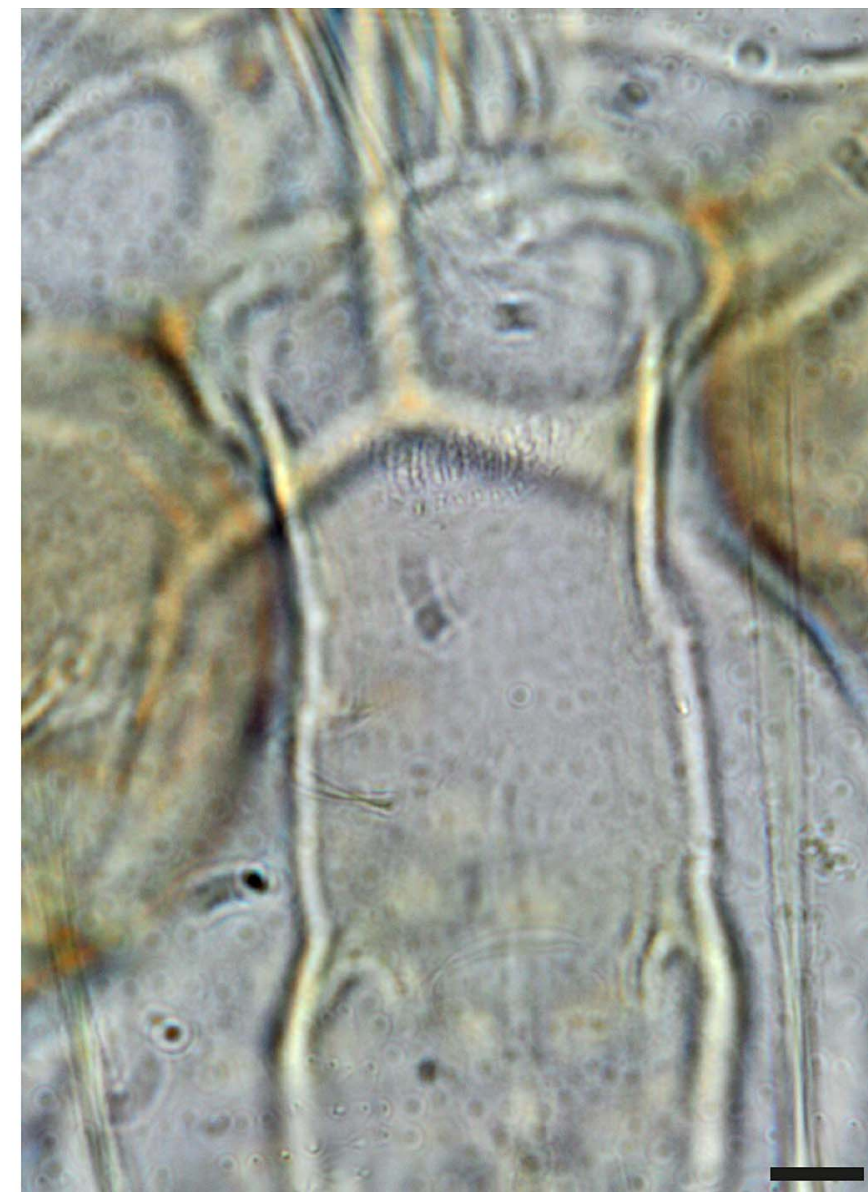

Figure 16. Cibarial armature of males of Sergentomyia sclerosiphon (A) and Se. anka (B). Bars $=10 \mu \mathrm{m}$.

different values: from 30 to 45 with an average of 37.7. Regarding the number of vertical teeth in the first row, we counted from 5 to 11 teeth (against 7-10 in the original description). Finally, we found in all of our samples, excepting one (MADA817), the second row of vertical teeth, which as in the original description, were within the range from 3 to 7 . In our material, the number of anterior vertical teeth varied from 1 to 7 .

The identification of Se. sclerosiphon females is mainly based on more widely spaced cibarial teeth with straight central ones. We counted 21-34 teeth versus 20-29 in the original description, and 7-22 vertical teeth in the first row versus $8-15$ in the original description. A second row of vertical teeth was not mentioned in the original description, but we found this additional row in 66 specimens out of the 218 examined. The number of vertical teeth constituting this most anterior row varies from 1 to 15 , but ranged between 8 and 15 in most of the specimens. In males, the nearly distal position of the accessory spine of the gonostyle does not seem to be very useful for their identification. Similarly, the length of the first flagellomere is of no use for species identification, as there is an overlap between two species: in Se. anka, the length varies from 158 to $248 \mu \mathrm{m}$ and in Se. sclerosiphon, from 179 to $287 \mu \mathrm{m}$. Consequently, if the length of the first flagellomere is less than $179 \mu \mathrm{m}$ or longer than $248 \mu \mathrm{m}$, identification is possible.
Finally, our morphological identifications were based exclusively on the cibarial armature.

The molecular approach highlights the difficulties involved with Vattieromyia taxonomy. The morphological approach is generally supported by the sequences of cytochrome b that classified both sexes into two branches for the majority of Se. anka and Se. sclerosiphon specimens. On the other hand, the D1 and D2 domains of the rDNA were insufficient to differentiate these two species. This observation highlights the conservation of this marker versus the great variability of cytochrome b. Some specimens are isolated: MADA 95 (ㅊ), MADA96 (ô), MADA199 (†), MADA819 (†), MADA876 (†), MADA893

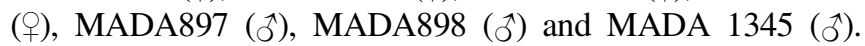
They draw our attention during their morphological examination due to their less typical cibarial armatures (Fig. 17). We carefully identified them as Se. cf anka. It is very interesting to note that both Cytb and D1 and D2 sequences clearly individualize these specimens. The genetic distance between these atypical specimens is $2.5 \%$ for cyt $b$ and $0.4 \%$ for D1 and D2. This is much higher than within other species. It is also much higher between these individuals than within true Se. anka or Se. sclerosiphon, for which the variability observed is only of $0.5 \%$ and $0.3 \%$, respectively (Tables 3 and 4). This genetic distance is close to the mean genetic distance between true Se. anka and 

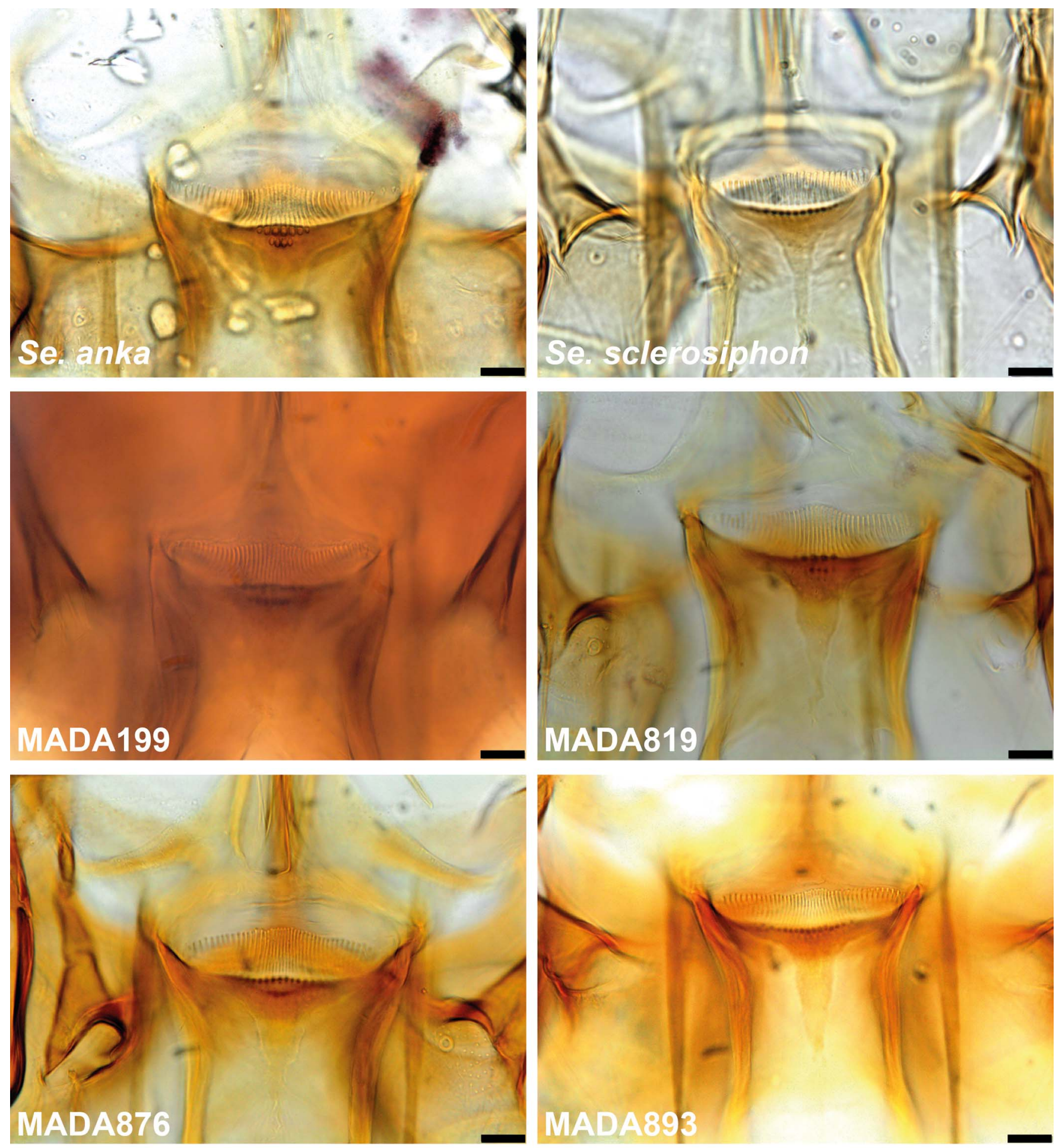

Figure 17. Comparison of the cibarial armatures of Sergentomyia anka and Se. sclerosiphon females with those of specimens identified as Se. cf. anka and isolated by molecular analyses. Bars $=10 \mu \mathrm{m}$.

Se. sclerosiphon. Nevertheless, we were not able to provide more definitive identification of these atypical specimens and they should not be considered a subspecific form due to their sympatry with $\mathrm{Se}$. anka and Se. sclerosiphon. It is possible that they represent some form of differentiation within Ankarana, but there is no strong morphological or molecular evidence to support their recognition as a new species and until further data are available, we consider these specimens atypical.

Morphological and molecular evidence supports the recognition of a new species: Se. volfi $\mathrm{n}$. sp. The spermathecae have a slightly wrinkled structure, without sclerotization, characters unknown in any named subgenus. The third segment of the 

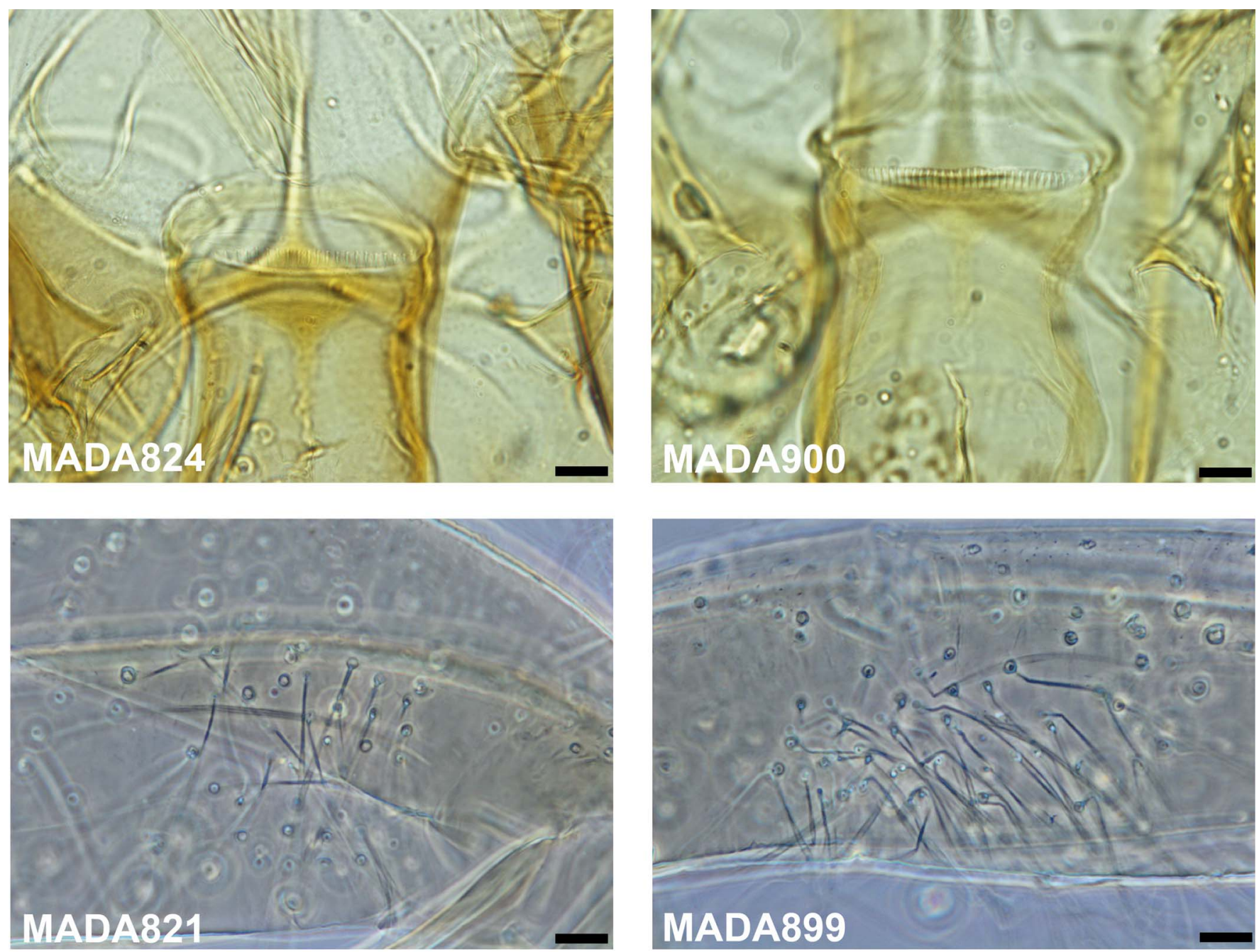

Figure 18. Sergentomyia (Ranavalonomyia) volfi n. sp. Cibarial armatures of two females exhibiting 20 (MADA824) or 30 (MADA900) teeth and coxites of two males exhibiting 9 (MADA821) and 23 setae (MADA899). Bars $=10 \mu \mathrm{m}$.

palp is particularly wide in the female and covered with a large number of Newstead's spines. Moreover, the absence of the ascoid on flagellomeres 1 and 2 in both males and females is seemingly unique in phlebotomine sandflies. The latter character, associated with the particular structure of the spermatheca, justify a new subgenus: Ranavalonomyia subg. nov. We also observed a unique distal fringe on top of flagellomeres f1-f6 in both females and males.

Molecular data show a high degree of intraspecific variability $(1.6 \%$ with cyt $b)$, which is related to morphological characters (Fig. 18), and seems to indicate two possible distinct populations. Regarding females, a wide range of cibarial teeth (20-31) was noted in our limited sampling $(p=0.51$, not statistically significant, passing the normality test of D'Agostino \& Pearson). For males, the number of gonocoxal setae varied from 9 to 24 ( $p=0.73$, not statistically significant, passing the normality test of D'Agostino \& Pearson). To our knowledge, this is a greater degree of intraspecific variability than has previously been observed in other species of phlebotomine sandflies. The morphological variables passed the D'Agostino \&
Pearson normality test. Without any greater evidence, we consider that all these specimens belong to the same species.

The association of males and females is strongly supported by their sequence homology.

The classification of Se. ozbeli n. sp. in the subgenus Rondanomyia is based on its spermatheca, which is distinctive in this group. Sergentomyia goodmani from Madagascar and its subspecies Se. goodmani comorensis from the Comoros do not have any cibarial vertical teeth. The identification of Se. ozbeli n. sp. is based on the existence of two rows of cibarial vertical teeth, the most anterior ones forming a continuous line completely crossing the sclerotized area.

Sergentomyia kaltenbachi $\mathrm{n}$. sp. is very different from the other Malagasy species. It has a cibarium with a very large number of teeth in the form of a palisade and a morphologically distinct spermatheca. The spermathecal body wall is finely wrinkled and exhibits a lateral spur, with a head embedded in the body. Considering the uniqueness of its spermatheca, we propose a new subgenus for this species: Riouxomyia subg. nov. 
Acknowledgements. The authors thank Nil Rahola for technical help and Steven M. Goodman for advice on an earlier version of the manuscript.

\section{References}

1. Abonnenc E. 1969. Sur Phlebotomus squamipleuris Newstead, 1912 et espèces voisines (Diptera: Psychodidae). Cahiers de l'ORSTOM, Série Entomologie Médicale et Parasitologie, 7(4), 307-323.

2. Abonnenc E. 1972. Les phlébotomes de la région éthiopienne (Diptera, Psychodidae). Mémoire ORSTOM, 55, 239 p.

3. Abonnenc E, Léger N. 1976. Sur une classification rationnelle des Diptères Phlebotomidae. Cahiers de l'ORSTOM, Série Entomologie Médicale et Parasitologie, 14, 69-78.

4. Bennai K, Tahir D, Lafri I, Bendjaballah-Laliam A, Bitam I, Parola P. 2018. Molecular detection of Leishmania infantum DNA and host blood meal identification in Phlebotomus in a hypoendemic focus of human leishmaniasis in northern Algeria. PLoS Neglected Tropical Diseases, 12(6), e0006513.

5. Bonfield J, Staden R. 1996. Experiment files and their application during large-scale sequencing projects. DNA Sequence, 6, 109-117.

6. Bongiorno G, Di Muccio T, Bianchi R, Gramiccia M, Gradoni L. 2019. Laboratory transmission of an Asian strain of Leishmania tropica by the bite of the southern European sand fly Phlebotomus perniciosus. International Journal for Parasitology, 49, 417-421.

7. Depaquit J, Léger N, Ferté H, Robert V. 2004. Les phlébotomes de Madagascar (Diptera: Psychodidae). II. Description de la femelle de Phlebotomus (Anaphlebotomus) fertei Depaquit, Léger \& Robert, 2002; description du mâle et redescription de la femelle de Phlebotomus (Anaphlebotomus) berentiensis (Léger \& Rodhain, 1978) comb. nov. Parasite, 11(2), 201-209.

8. Depaquit J, Léger N, Randrianambinintsoa FJ. 2015. Paraphyly of the subgenus Anaphlebotomus and creation of Madaphlebotomus subg. nov. (Phlebotominae: Phlebotomus). Medical and Veterinary Entomology, 29(2), 159-170.

9. Depaquit J, Léger N, Robert V. 2002. Première mention de Phlebotomus à Madagascar (Diptera: Psychodidae). Description de Phlebotomus (Anaphlebotomus) fertei n. sp. et de Phlebotomus (Anaphlebotomus) huberti n. sp. Parasite, 9(4), 325-331.

10. Depaquit J, Léger N, Robert V. 2004. Les Phlébotomes de Madagascar (Diptera: Psychodidae). III-Description de Phlebotomus (Anaphlebotomus) fontenillei n. sp. Parasite, 11(3), 261-265.

11. Depaquit J, Léger N, Robert V. 2007. Les phlébotomes de Madagascar (Diptera: Psychodidae). V-. Description de Sergentomyia majungaensis n. sp. Parasite, 14(3), 219-223.

12. Depaquit J, Léger N, Robert V. 2008. Les phlébotomes de Madagascar (Diptera: Psychodidae). VI-Un sous-genre nouveau (Vattieromyia) avec trois espèces nouvelles: Sergentomyia $(V$.) sclerosiphon, $S$. (V.) namo et $S$. (V.) anka. Parasite, 15(1), 15-26.

13. Depaquit J, Perrotey S, Lecointre G, Tillier A, Tillier S, Ferté H, Kaltenbach M, Léger N. 1998. Systématique moléculaire des Phlebotominae: étude pilote. Paraphylie du genre Phlebotomus. Comptes Rendus de l'Académie des Sciences III, 321(10), 849-855.

14. Esseghir S, Ready PD, Killick-Kendrick R, Ben-Ismail R. 1997. Mitochondrial haplotypes and geographical vicariance of Phlebotomus vectors of Leishmania major. Insect Molecular Biology, 6(3), 211-225.
15. Galati EAB, Galvis-Ovallos F, Lawyer P, Léger N, Depaquit J. 2017. An illustrated guide for characters and terminology used in descriptions of Phlebotominae (Diptera, Psychodidae). Parasite, 24, 26.

16. Galvis-Ovallos F, da Silva MD, Bispo GB, de Oliveira AG, Neto JR, Malafronte RD, Galati EA. 2017. Canine visceral leishmaniasis in the metropolitan area of Sao Paulo: Pintomyia fischeri as potential vector of Leishmania infantum. Parasite, 24, 2.

17. Gonzalez E, Jimenez M, Hernandez S, Martin-Martin I, Molina R. 2017. Phlebotomine sand fly survey in the focus of leishmaniasis in Madrid, Spain (2012-2014): seasonal dynamics, Leishmania infantum infection rates and blood meal preferences. Parasites and Vectors, 10(1), 368.

18. Goodman S, Raherilalao M, Wohlhause S. 2018. Les aires protégées terrestres de Madagascar : Leur histoire, description et biote. [The terrestrial protected areas of Madagascar: Their history, description, and biota]. Antananarivo: Association Vahatra. $1716 \mathrm{p}$.

19. Hall T. 1999. Bioedit: a user-friendly biological sequence alignment editor and analysis program for Windows 95/98/NT. Nucleic Acids Symposium Series, 4, 95-98.

20. Hawkins F, Chapman P, Ganzhorn J, Bloxam Q, Barlow S, Tonge SJ. 1990. Vertebrate conservation in Ankarana Special Reserve, northern Madagascar. Biological Conservation, 54, 83-110.

21. ICZN. 1999. International Code of Zoological Nomenclature. London: The International Trust for Zoological Nomenclature. http://www.nhm.ac.uk/hosted-sites/iczn/code/.

22. Jaouadi K, Haouas N, Chaara D, Boudabous R, Gorcii M, Kidar A, Depaquit J, Pratlong F, Dedet JP, Babba H. 2013. Phlebotomine (Diptera, Psychodidae) bloodmeal sources in Tunisian cutaneous leishmaniasis foci: could Sergentomyia minuta, which Is not an exclusive herpetophilic species, be implicated in the transmission of pathogens? Annals of the Entomological Society of America, 106(1), 79-85.

23. Killick-Kendrick R. 1990. Phlebotomine vectors of the leishmaniases: a review. Medical and Veterinary Entomology, 4, $1-24$.

24. Kumar S, Stecher G, Tamura K. 2016. MEGA7: molecular evolutionary genetics analysis Version 7.0 for bigger datasets. Molecular Biology and Evolution, 33(7), 1870-4.

25. Lawyer P, Killick-Kendrick M, Rowland T, Rowton E, Volf P. 2017. Laboratory colonization and mass rearing of phlebotomine sand flies (Diptera, Psychodidae). Parasite, 24, 42.

26. Léger N, Depaquit J, Robert V. 2005. Les phlébotomes de Madagascar (Diptera: Psychodidae). IV. Description de Sergentomyia (Rondanomyia) goodmani n. sp. Rétablissement du sous-genre Rondanomyia Theodor. Parasite, 12(1), 51-57.

27. Lourenço W, Goodman S. 2008. Scorpions of the Réserve spéciale d'Ankarana, Madagascar, with particular reference to cave-dwelling animals and the description of two new species (Arachnida, Scorpiones). Zoosystema, 30(3), 665-679.

28. Maia C, Depaquit J. 2016. Can Sergentomyia (Diptera, Psychodidae) play a role in the transmission of mammalinfecting Leishmania? Parasite, 23, 55.

29. Niang A, Hervy J, Depaquit J, Boussès P, Davidson I, Geoffroy B, Léger N, Trouillet J, Killick-Kendrick R, Killick-Kendrick M, Rioux J, Brunhes J, Editors. 2004. Les Phlébotomes de la région afro-tropicale : logiciel d'identification et d'enseignement. [Sand Flies of the Afrotropical Region: An identification and training programme]. Paris: IRD Editions.

30. Randrianambinintsoa FJ, Depaquit J. 2013. Phlebotomine sand flies from Madagascar (Diptera: Psychodidae). VIII - Phlebotomus (Anaphlebotomus) vincenti $\mathrm{n}$. sp. Bulletin de la Société de Pathologie Exotique, 106, 206-211. 
31. Randrianambinintsoa FJ, Depaquit J, Brengues C, Dhondt C, Yahaya I, Ouledi A, Léger N, Robert V. 2012. First record of Phlebotomine sandflies (Diptera: Psychodidae) in the Comoros Archipelago with description of Sergentomyia (Vattieromyia) pessoni n. sp. and S. (Rondanomyia) goodmani comorensis $\mathrm{n}$. ssp. Parasite, 19, 195-206.

32. Randrianambinintsoa FJ, Léger N, Robert V, Depaquit J. 2013. Phlebotomine sand flies from Madagascar (Diptera: Psychodidae). VII. An identification key for Phlebotomus with the description of Phlebotomus (Anaphlebotomus) vaomalalae $\mathrm{n}$. sp. Parasite, 20, 6.

33. Randrianambinintsoa FJ, Léger N, Robert V, Depaquit J. 2014. Paraphyly of the subgenus Sintonius (Diptera, Psychodidae, Sergentomyia): status of the Malagasy species. Creation of a new subgenus and description of a new species. PLoS One, 9 (6), e98065.

34. Raynal J, Le Gac P. 1937. Phlébotomes dans le nord de Madagascar. Phlebotomus squamipleuris Newstead 1912. Bulletin de la Société de Pathologie Exotique, 30, 76-90.
35. Robert V, Ramasindrazana B, Goodman S. 2014. The species composition and distribution of insects collected by light-traps, with special reference to hematophagous groups, in and near cave systems of Madagascar. Malagasy Nature, 8, 54-66.

36. Senghor MW, Niang AA, Depaquit J, Ferte H, Faye MN, Elguero E, Gaye O, Alten B, Perktas U, Cassan C, Faye B, Bañuls AL. 2016. Transmission of Leishmania infantum in the canine leishmaniasis focus of Mont-Rolland, Senegal: ecological, parasitological and molecular evidence for a possible role of Sergentomyia Sand Flies. PLoS Neglected Tropical Diseases, 10(11), e0004940.

37. Svobodova M, Votypka J, Peckova J, Dvorak V, Nasereddin A, Baneth G, Sztern J, Kravchenko V, Orr A, Meir D, Schnur LF, Volf P, Warburg A. 2006. Distinct transmission cycles of Leishmania tropica in 2 adjacent foci, Northern Israel. Emerging Infectious Diseases, 12(12), 1860-1868.

38. Thompson J, Higgins D, Gibson T. 1994. Clustal W: improving the sensivity of progressive multiple sequence alignment through sequence weighting, position-specific gap penalties and weight matrix choice. Nucleic Acids Research, 22, 4673-4680.

Cite this article as: Blavier A, Laroche L, Randrianambinintsoa FJ, Lucas V, Gantier J-C, Léger N, Robert V \& Depaquit J. 2019. Phlebotomine sandflies (Diptera, Psychodidae) from the Ankarana tsingy of northern Madagascar: inventory and description of new taxa. Parasite 26, 38.

\section{OPARASTE}

An international open-access, peer-reviewed, online journal publishing high quality papers on all aspects of human and animal parasitology

Reviews, articles and short notes may be submitted. Fields include, but are not limited to: general, medical and veterinary parasitology; morphology, including ultrastructure; parasite systematics, including entomology, acarology, helminthology and protistology, and molecular analyses; molecular biology and biochemistry; immunology of parasitic diseases; host-parasite relationships; ecology and life history of parasites; epidemiology; therapeutics; new diagnostic tools.

All papers in Parasite are published in English. Manuscripts should have a broad interest and must not have been published or submitted elsewhere. No limit is imposed on the length of manuscripts.

Parasite (open-access) continues Parasite (print and online editions, 1994-2012) and Annales de Parasitologie Humaine et Comparée (1923-1993) and is the official journal of the Société Française de Parasitologie. 